\title{
IMPACTOS DA MUNDIALIZAÇÃO SOBRE UMA METRÓPOLE PERIFÉRICA
}

\author{
Wagner Iglecias
}

A cidade de São Paulo tem se notabilizado por manter a posição de liderança na economia brasileira, embora, juntamente com o Estado de São Paulo, venha sofrendo, nas últimas décadas, um processo de desindustrialização e diminuição de sua participação no Produto Interno Bruto do país. O novo modelo de inserção do Brasil na economia mundial, pautado por reformas estruturais de caráter liberalizante, tem como uma de suas mais importantes expressões espaciais a consolidação da capital paulista como pólo de conexão da economia e do território brasileiros com os fluxos globais de capital. São Paulo tem adquirido, assim, nos últimos anos, características de uma metrópole informacional, deixando de ser uma economia de produção de bens para tornarse uma economia de desempenho de funções. A cidade segue a mesma tendência observada nas mais importantes metrópoles do planeta e, à medida que o Brasil se integra à economia mundial, passa a ser mais um centro de articulação do capitalismo contemporâneo, alçado à condição de sistema mundial. ${ }^{1}$

O processo de transformação da vocação econômica da cidade de São Paulo acentuou-se durante a década de 1990, e entre as inúmeras e diversificadas atividades terciárias, tem cabido à capital paulista concentrar os centros decisórios das corporações cujos produtos e serviços caracterizam o capitalismo transnacionalizado da época atual. Em São Paulo estão as matrizes brasileiras da maior parte das empresas de finanças, tecnologia, mídia, telecomunicações, publicidade, consultoria empresarial e companhias "ponto.com" em atividade no país. Na capital paulista concentram-se ainda os segmentos mais qualificados do mercado de trabalho brasileiro, a maior universidade e alguns dos melhores centros de pesquisa do país, a maior infra-estrutura de telecomunicações do território nacional, o maior mer- 
cado consumidor e a melhor rede de serviços corporativos de apoio às atividades de gestão do grande capital (hotéis, centros de convenções, shopping centers, restaurantes, espaços de cultura e lazer etc.), entre outras características.

Na metrópole de São Paulo localizavam-se, em 1998, as sedes de 35 dos cem maiores grupos empresariais brasileiros. Entre as cem maiores empresas estrangeiras com atividades no Brasil, 54 tinham suas matrizes sediadas na capital paulista ou nas cidades de sua região metropolitana. Entre os cem maiores bancos privados nacionais, 44 tinham sede em São Paulo e um em Osasco, cidade vizinha. Entre os bancos estrangeiros em atividade no país, que não chegam a contabilizar uma centena, 94\% possuíam suas matrizes brasileiras na cidade de São Paulo.

Enquanto no segmento dos maiores grupos nacionais e estrangeiros a metrópole paulista concentra o maior número de sedes de empresas, embora - em razão de recentes fusões e privatizações de companhias -, seja crescente o número de corporações com sedes em vários Estados do Brasil, no setor financeiro a primazia da cidade de São Paulo é incontestável. Entre os dez maiores bancos privados nacionais, sete tinham sede em São Paulo no ano de 1998. Entre os dez maiores bancos estrangeiros em atividade no país naquele mesmo ano, nove tinham suas matrizes na capital paulista. Além disso, a recente transferência da parcela do mercado de capitais que cabia à Bolsa de Valores do Rio de Janeiro para a de São Paulo tem concentrado a quase totalidade das corretoras de valores na cidade de São Paulo. Não bastasse a concentração crescente destas empresas na capital paulista, a maior parte delas instala suas sedes na porção sudoeste do município, alçada quase à condição de um novo centro da cidade.

A capital paulista caracterizou-se, no decorrer do século XX, por concentrar as funções de comando de cada etapa histórica de desenvolvimento do capitalismo brasileiro. A formação, na década de 1990, de uma nova centralidade na cidade - para onde convergem as funções de articulação do mercado e do território brasileiros com a economia mundializada - é o objeto de reflexão do presente texto, ainda que, por mais paradoxal que possa parecer, esse novo centro da cidade de São Paulo se localize territorialmente junto à parcela mais excluída da periferia paulistana. Como afirmou Milton Santos, a metrópole paulista vive um processo de mundialização incompleto, seletivo e desigual. Nela se justapõem e se superpõem traços de opulência, devidos à pujança da vida

Tabela 1

Concentração das Sedes das Grandes Corporações por Estado -1998* (\%)

\begin{tabular}{c|c|c|c|c}
\hline & $\begin{array}{c}\text { CEM MAIORES } \\
\text { EMPRESAS PRIVADAS } \\
\text { NACIONAIS }\end{array}$ & $\begin{array}{c}\text { CEM MAIORES } \\
\text { EMPRESAS ESTRANGEIRAS }\end{array}$ & $\begin{array}{c}\text { CEM MAIORES } \\
\text { BANCOS PRIVADOS } \\
\text { NACIONAIS }\end{array}$ & $\begin{array}{c}\text { BANCOS } \\
\text { ESTRANGEIROS }\end{array}$ \\
\hline $\begin{array}{c}\text { Região. } \\
\text { Metropolitana de SP }\end{array}$ & 35 & 54 & 45 & 94 \\
Interior de SP & 3 & 7 & 0 & 3 \\
RJ & 18 & 13 & 22 & 0 \\
RS & 9 & 4 & 7 & 0 \\
MG & 6 & 7 & 5 & 0 \\
BA & 7 & 1 & 2 & 3 \\
\hline Outros Estados & 22 & 14 & 19 & 100 \\
\hline TOTAL & 100 & 100 & 100 & 0 \\
\hline
\end{tabular}

* Por Receita Operacional Líquida

Fonte: Balanço Anual - Gazeta Mercantil 
econômica, bem como suas expressões materiais e sinais de desfalecimento, graças ao atraso das estruturas sociais e políticas. Tudo o que há de mais moderno pode aí ser encontrado, ao lado das carências mais gritantes (Santos, 1990).

A magnitude das transformações pelas quais tem passado a economia mundial no último quarto de século permite inclusive que se avance em alguns aspectos da clássica leitura que Braudel e Wallerstein fizeram do processo de desenvolvimento do capitalismo. Efetivamente transformado numa economia-mundo de proporções planetárias, o capitalismo contemporâneo parece não mais se organizar em zonas simplesmente concêntricas, mas, em razão das possibilidades da revolução tecnológica das últimas décadas, em forma de uma extensa rede composta de áreas geográficas específicas pelas quais circulam seus fluxos de mundialização (Castells, 2000). Está em curso um processo de redefinição das relações clássicas entre o centro e a periferia do sistema, e é a interação entre um grupo de cidades dispersas espacialmente pelo mundo que possibilita a organização e a otimização das funções da valorização do capital em escala global. Uma espécie de nova Liga Hanseática, cujos limites e dimensões são agora planetários. De fato, muitos centros urbanos são desnacionalizados, ou mundializados, e ainda que cada metrópole possua suas particularidades históricas próprias e sofra os impactos da mundialização a seu modo, os lugares específicos que as metrópoles representam na economia global têm sido transformados por uma dinâmica comum, caracterizada pela mobilidade crescente do capital. É possível que esteja em curso a formação de um enorme sistema urbano, de caráter transnacional. É por meio deste novíssimo sistema urbano que se expressa material e territorialmente a mundialização do capital. Obviamente, tal expressão não se restringe a este sistema urbano, como nos mostra o exemplo dos tecnopólos, mas é nele que se concretizam seus aspectos mais importantes. ${ }^{2}$

Parece não existir, porém, um tipo ideal de cidade no capitalismo contemporâneo, mas apenas um sistema de cidades nos quais se articulam os processos de mundialização das relações capitalistas. Neste sistema urbano transnacional as di- ferentes metrópoles ocupam nichos específicos dentro das hierarquias funcionais nele estabelecidas. Embora remonte ao início do século XX, O conceito de sistema mundial de cidades voltou a ganhar fôlego nos anos de 1980, a partir de um artigo de John Friedman e Goertz Wolff em que os autores procuravam relacionar a emergência de novos processos de urbanização em grandes metrópoles do mundo a forças econômicas globais. ${ }^{3}$ A bibliografia sobre as cidades globais ou mundiais é extensa e bastante heterogênea, congregando desde os entusiastas da idéia de que as grandes metrópoles mundiais inserem-se, de modo crescentemente competitivo, numa seara global pautada pela luta por investimentos privados até os que acreditam que, como categoria analítica, o conceito de "cidade global" ou "cidade mundial" aplica-se a um reduzidíssimo conjunto de metrópoles, as quais efetivamente concentram as funções de comando e controle da economia contemporânea. Autores seminais na questão das "cidades globais", como John Friedman e Saskia Sassen, sustentam que tais metrópoles articulam espaços regionais, nacionais e internacionais na economia mundial, sendo que entre aquelas que articulam espaços internacionais existem as mais notabilizadas, responsáveis pelas funções de controle e comando das articulações financeiras mundiais. Neste seleto grupo estariam Nova York, Londres e Tóquio. ${ }^{4}$

Embora seja arriscada a comparação entre cidades tão distintas quanto Tóquio, Londres e Nova York, ou São Paulo, Seul e México, ao se tomar por semelhantes realidades muito diversas, cumpre notar que há uma série de características econômicas, sociais, culturais e políticas comuns que são cada vez mais perceptíveis em todas essas aglomerações urbanas. ${ }^{5}$ As diversas metrópoles que fazem parte do sistema urbano mundializado deixaram de ser centros industriais e tiveram parte de sua economia urbana transformada pelo desempenho de novos papéis, sobretudo os relacionados às funções de comando e controle dos processos de valorização do capital que se difundem territorialmente pelo mundo. Elas são, na sua maioria, cidades "pós-fordistas", com o predomínio do setor de serviços e emprego de recursos 
tecnológicos avançados em grande parte dos processos produtivos; sediam o capital global, ou suas filiais espalhadas pelo mundo, com destaque para os grandes conglomerados financeiros mundiais, as administrações das corporações transnacionais e todos os serviços altamente qualificados a eles associados (também chamados de setor quaternário), como os grandes escritórios de auditoria e consultoria empresarial, as grandes seguradoras, os fundos de pensão, as bancas de advocacia, as agências de publicidade, os centros de pesquisa universitária etc. Nessas metrópoles concentram-se também as sedes das corporações dos setores de mídia, informática e telecomunicações, responsáveis pela profusão de produtos como notícias, cultura, tecnologias, estilos de vida etc. Maiores centros econômicos de seus respectivos países ou regiões são, em geral, os seus maiores centros financeiros, comerciais e turísticos. Constituem os maiores mercados consumidores e as maiores áreas metropolitanas de seus países. São destinos de fluxos de emigração e imigração e concentram os mais importantes portos e aeroportos de seus países. ${ }^{6}$

As forças econômicas globais incidem não apenas sobre a funcionalidade econômica dessas cidades, mas também sobre suas estruturas socioespaciais. Essas metrópoles sofrem fortes processos de desindustrialização, com o abandono de áreas geográficas inteiras que não conseguiram superar o paradigma de produção anterior (fordismo, economia de escala, linha de produção contínua e pouco flexível etc.). Por conseguinte, enfrentam o desemprego estrutural, devido tanto às inovações dos processos produtivos quanto à baixa qualificação de grande parte de seus contingentes de mão-de-obra urbana. Esta dinâmica tem conduzido à informalização e à precarização das relações de trabalho, com a proliferação de atividades desenvolvidas à margem da economia formal, bem como à deterioração urbana de modo geral, expressa na decadência dos padrões de qualidade de vida, no aumento da criminalidade violenta, na degradação ambiental etc. Territorialmente, os impactos das transformações nos principais mercados de trabalho dessas grandes cidades referem-se à polarização socioespacial urbana, com a formação de espaços urbanos extremamente diferenciados e segmentados, como os enclaves fortificados, os guetos, os centros empresariais sofisticados, os shoppings centers etc. No entanto, a transformação das funções econômicas das cidades parece não conduzir, necessariamente, como afirmam alguns autores, à dualização do mercado de trabalho urbano e tampouco a reflexos disso na totalidade da espacialidade urbana. ${ }^{7}$ A importância e a diversidade econômicas das metrópoles e o desempenho das novas funções relativas às conexões com os fluxos globais do capital podem dar origem a uma vasta gama de atividades intermediárias, tanto salarial quanto funcionalmente. O que caracteriza as grandes metrópoles na atualidade é a visibilidade de um extraordinário contraste social por ocasião da proximidade espacial de uma extrema riqueza ou pobreza, aparente em determinados bairros ou regiões da cidade, e não obrigatoriamente em todo o espaço urbano.

Nas cidades conectadas aos fluxos globais de capital, convivem num mesmo território, dois circuitos econômicos crescentemente apartados. Ao mesmo tempo em que a casta de funcionários envolvidos na gestão do capital transnacional se mundializa, por meio da interligação cotidiana com seus pares alocados em outras regiões do mundo, desenvolve-se nessas metrópoles um lumpen proletariado praticamente descartado da economia formal, também denominado de underclass, lumpentrash etc., e altamente fragmentado, tanto em razão da feroz disputa pelos parcos recursos disponíveis às parcelas urbanas mais pauperizadas, como por clivagens variadas, relativas à etnia, à religião, à localização geográfica no meio urbano etc. ${ }^{8}$ A reestruturação econômica e a mudança social das grandes cidades resultam na criação de uma massa de indivíduos pobres progressivamente isolados, cujas chances de avançar em termos de mobilidade econômica e social são muito pequenas. As mudanças estimuladas pela reestruturação econômica mundial fizeram com que as agências governamentais municipais desenvolvam estratégias para tornar suas cidades competitivas em termos de atração de investimentos privados. Os segmentos sociais menos favorecidos são vitimizados tanto pelo desaparecimento 
dos postos de trabalho quanto pelas inversões de prioridades nas intervenções públicas, crescentemente voltadas à viabilização de atividades corporativas. O caso de São Paulo é modelar neste sentido, conforme veremos adiante.

\section{Os dois modos de construção da cidade}

O tema do crescimento vertiginoso e desigual da metrópole de São Paulo no decorrer do século XX já é relativamente conhecido. Existe uma significativa literatura a respeito, desenvolvida principalmente por cientistas sociais e urbanistas paulistas. Em geral, as pesquisas e reflexões sobre o tema apontam para um modelo de crescimento que se deu de modo discriminatório, por parte do poder público, em relação aos diversos contingentes socioeconômicos presentes na metrópole (Singer, 1975; Santos, 1990; Kowarick, 1994; Maricato, 1996). Algumas pesquisas apontam questões mais específicas, como a da habitação, e mostram como, desde as primeiras décadas da industrialização paulista, a questão da moradia foi bastante problemática para as classes trabalhadoras, obrigando-as a desenvolver estratégias que resultaram em encortiçamento, favelização e autoconstrução de casas em loteamentos periféricos (Bonduki, 1994). Outros estudos demonstram as estratégias desenvolvidas pelas elites paulistanas para isolarem-se das camadas populares, criando espaços sociais diferenciados e exclusivos na metrópole, bem como o abandono recorrente desses espaços e sua ressignificação por parte das classes populares (Rolnik, 1994; Frúgoli, 1998).

A polarização entre as "terras altas", nos bairros de Campos Elíseos, Higienópolis e Avenida Paulista, e as "terras baixas", nos bairros do Brás, Bom Retiro e Barra Funda, que opunha industriais e barões do café a operários no início do século $\mathrm{XX}$, atravessou as décadas e reproduziu-se em outros territórios da capital paulista. Ao lado de uma ideologia reacionária, que substituiu a mentalidade higienista da elite paulistana do início do século pela especulação imobiliária pura e simples sobre terrenos ocupados pela população de baixa renda, sempre se manteve historicamente o desejo de auto-isolamento dos mais ricos e a tendên- cia de concentração, num mesmo espaço urbano, das atividades de gestão do grande capital e a moradia das camadas mais abastadas da população. É por conta desta conjunção de fatores que a história da urbanização da cidade de São Paulo é a história da periferização da pobreza e da criação e do abandono de centralidades.

A periferização da cidade, que é responsável pelas medidas grandiosas que caracterizam São Paulo e sua região metropolitana, se deu em todas as direções geográficas, em especial nos quadrantes sul e leste. A criação de novas centralidades, porém, obedece há décadas um percurso, a partir do centro histórico da cidade, em direção ao quadrante sudoeste. Enquanto nos primeiros tempos da industrialização paulistana a Praça da Sé e seu entorno concentravam as atividades políticas, sociais e econômicas desenvolvidas pelas elites, com o decorrer das décadas, no entanto, o centro histórico teve suas funções econômicas redefinidas e a Avenida Paulista e arredores consolidaram sua hegemonia como bolsão residencial dos setores sociais mais elevados e como centro de serviços sofisticados, passando a sediar empresas do setor terciário, como os grandes bancos paulistas.

Durante os anos de 1960 um boom imobiliário consolidou a tendência paulistana de concentrar numa mesma região da cidade a moradia da elite econômica e as atividades de ponta do capital. A expansão do bairro dos Jardins, iniciada ainda nas primeiras décadas do século, atingiu naquele período a margem do rio Pinheiros e uniu-se ao então ainda pouco habitado bairro do Morumbi. A Avenida Brigadeiro Faria Lima, que corta a região, foi alçada à condição de vetor desta nova expansão do centro em direção à região sudoeste da cidade. A extensão imaginária da Faria Lima, composta pelo traçado ligando a imensa área entre os bairros de Itaim e de Santo Amaro, paralela ao rio Pinheiros, começava, a partir de então, a ser objeto de um novo movimento de especulação imobiliária e valorização urbana. Centenas de terrenos, muitos ainda vazios, ou ocupados por galpões industriais e residências de classe média, foram adquiridos por grandes agentes imobiliários e estocados, numa estratégia de valorização a longo prazo. Poucas plantas fabris foram instaladas na região a partir de então, e to- 
das as apostas do mercado imobiliário apontavam para o crescimento das atividades de serviços em direção ao bairro de Santo Amaro.

Santo Amaro, aliás, desde os anos de 1950 já se notabilizava como a principal região fabril da cidade. O antigo município de vocação agrícola, situado ao sul da capital paulista, se transformaria, a partir dos anos de 1960, numa região vastamente povoada, principalmente pelas camadas populares, formadas por milhares de trabalhadores migrantes que afluíam para a metrópole atraídos pelo emprego industrial ou pelas atividades de suporte a ele. Acompanhando o rio Pinheiros e a antiga linha da ferrovia Sorocabana, estabeleceu-se ali o principal pólo da grande indústria no município de São Paulo. Os trabalhadores empregados nas fábricas ocuparam, ao longo do tempo, as regiões menos valorizadas, nos barrancos entre as represas (enfrentando uma legislação de proteção dos mananciais que impediria a ocupação dessas áreas) e, no lado oeste do Pinheiros, adensando a ocupação de distritos como Campo Limpo e Capela do Socorro, e ao longo das estradas do M'Boi Mirim e Itapecerica. A chegada dessa população operária transfigurou completamente o antigo bairro de Santo Amaro, sendo a expressão mais visível disso o Largo Treze de Maio, espaço central de toda a região. Ele se tornou não apenas ponto regional de conexão dos transportes, mas também centro de comércio e convivência onde ressaltam os traços de uma cultura nordestina transplantada (Sader, 1988).

\section{Cenesp e Berrini: marcos históricos e geográficos}

O traçado entre a Avenida Brigadeiro Faria Lima e o bairro de Santo Amaro experimentou, entre as décadas de 1970 e 1990, tanto uma brutal valorização imobiliária quanto uma modificação significativa de sua vocação econômica e de sua paisagem arquitetônica. A região já possuía uma série de equipamentos urbanos, construídos pelo poder público, que constituíam seu potencial como futura extensão territorial das atividades de gestão do grande capital. Entre eles destacam-se as marginais do rio Pinheiros e o Aeroporto de Congonhas, bem como uma diversificada malha viária que desde o início do século servia de interligação entre o bairro de Santo Amaro e o centro da cidade.

No espaço de vinte anos formou-se o maior distrito corporativo do país. A região urbana aqui denominada "Vetor Sudoeste" refere-se à extensão da Avenida das Nações Unidas, também conhecida como Marginal Pinheiros, compreendida no trecho de cinco quilômetros entre a Avenida dos Bandeirantes e a Ponte Transamérica, na zona sudoeste da cidade de São Paulo. Neste trecho, outrora caracterizado pela presença de plantas e galpões industriais, bairros residenciais de classe média e terrenos baldios, à margem direita, e por favelas e bairros de classe média baixa, à margem esquerda do rio Pinheiros, está se formando, desde o início dos anos de 1990, a região terciária mais dinâmica da América Latina. Na margem direita do rio estão sendo construídos os maiores, mais caros e mais avançados empreendimentos imobiliários do país, nos quais se instalam corporações brasileiras e transnacionais de setores de ponta da economia contemporânea, bem como hotéis de luxo, centros de consumo sofisticado e infra-estrutura diferenciada de lazer. Na margem esquerda do rio consolidam-se os bairros habitados por populações de baixa renda. ${ }^{10}$

Os marcos históricos e territoriais do Vetor Sudoeste são o Centro Empresarial São Paulo, fundado em 1977, e a Avenida Eng. Luiz Carlos Berrini, construída sob uma região de várzea, por conta dos empreendimentos imobiliários ali realizados pela construtora e incorporadora Bratke e Collet. No Centro Empresarial São Paulo concentram-se sedes de algumas grandes corporações e na Berrini existem mais de quarenta edifícios onde espalham-se centenas de empresas de suporte às transnacionais que se instalaram em todo o Vetor Sudoeste. Enquanto a Berrini, situada no bairro do Brooklin, interliga-se à Avenida dos Bandeirantes e aos bairros do Itaim, Moema e Aeroporto, numa região relativamente próxima ao centro da cidade, o Centro Empresarial São Paulo localiza-se quase no outro extremo da Marginal Pinheiros, próximo ao centro de Santo Amaro e ao Jardim São Luís, bairro situado à margem esquerda do rio e porta de entrada da periferia da zona sul de São Paulo. ${ }^{11}$ 
O bairro do Brooklin faz parte do cinturão de regiões intermediárias entre o centro da cidade de São Paulo e o antigo município de Santo Amaro, e começou a ser urbanizado ainda na década de 1910, quando já havia interligação férrea entre as duas localidades. O Brooklin é, efetivamente, uma região que sofre processos de especulação e valorização imobiliária desde o início do século XX. O bairro que tinha, até meados dos anos de 1970, uso predominantemente residencial e, em menor escala, industrial, tornou-se, a partir dos anos de 1980, o entorno da mais marcante intervenção do capital privado sobre o traçado urbano da história da cidade de São Paulo. A construção da Berrini, a avenida que corta o bairro, foi uma invenção da Bratke Collet, numa operação praticamente monopolista (Fujimoto, 1994; Frúgoli, 1988). Já o bairro do Jardim São Luís tem sua origem no processo de periferização da cidade, formado por áreas até hoje pouco valorizadas pelo mercado imobiliário e habitadas pelas populações de baixa renda, que nele difundiram o padrão tradicional de moradia popular em São Paulo, com a multiplicação de favelas e a autoconstrução de casas próprias.

Em termos arquitetônicos, o Vetor Sudoeste destaca-se de todas as outras regiões da cidade. Os vários prédios erguidos na extensão da Marginal Pinheiros nos últimos anos caracterizam-se pelo estilo "pós-moderno". As torres rompem com a austeridade da arquitetura modernista, que valorizava as formas retas e funcionais, a parcimônia das cores e, como materiais, o concreto e o vidro. Há um uso maior de diagonais, de volumes que saem do retângulo ou criam incisões nele, de elementos lúdicos, de materiais coloridos, de transparências, de sacadas e paisagismos. O andar térreo da maioria das torres possui um saguão com pé direito alto e bastante jardinagem. Trata-se de uma arquitetura que não se pretende tão racionalista quanto a modernista, dando mais espaço à subjetividade dos efeitos e ornamentos. No lugar do concreto, experimentam-se combinações inusitadas entre granito e vidro, diagonais, cilindros longitudinais, alumínio, reentrâncias, originando uma simetria inusitada das formas dos prédios com a planície espelhada do rio Pinheiros e configurando um skyline totalmente novo no horizonte da cidade e completamente diverso da tradicional imagem da São
Paulo cinzenta dos mil prédios, que tanto caracterizou a metrópole em seu período industrial. ${ }^{12}$

Não há, em todo o território nacional, concentração tão expressiva de empreendimentos com padrão de construção e funcionamento tão avançados quanto no Vetor Sudoeste da capital paulista. As torres de escritórios que estão sendo construídas na região incorporam também toda sorte de inovações tecnológicas em termos de administração predial, segurança patrimonial e infraestrutura de telecomunicações internacionais. Estas torres são popularmente conhecidas como "prédios inteligentes". Possuem área de laje superior a $1000 \mathrm{~m}^{2}$, sistema de ar-condicionado central (ACC), sistema de termoacumulação, sistema de regulagem automática da iluminação artificial interna dos prédios de acordo com a luz vinda do ambiente externo, estruturas flexíveis para upgrades de hardware e de telecomunicações, toda sorte de equipamentos para o estabelecimento de conexões com qualquer parte do mundo, como redes corporativas de intranet, internet e salas de video-conferência ligadas por antena via satélite a diversas localidades do mundo, além de avançados sistemas de segurança predial, como detectores de variações bruscas da temperatura ambiente e sistemas anti-incêndio. As instalações internas são bastante flexíveis e permitem modificações de utilização de energia e de layout, providenciais para os upgrades de hardware que se sucedem a cada ano.

\section{Real Parque e Peinha: marcos da fronteira}

Enquanto a margem direita do rio Pinheiros se notabiliza por concentrar as sedes de algumas das mais importantes corporações transnacionais do setor terciário avançado, na margem esquerda do mesmo rio situam-se duas favelas, Real Parque e Peinha, cuja fundação data dos anos de 1960, e cuja localização em frente ao novíssimo distrito de negócios configura uma espacialidade bastante típica das grandes metrópoles mundiais no atual período de expansão capitalista, com uma pronunciada proximidade física entre realidades socioeconômicas extremamente díspares. São comunidades que foram poupadas do processo recente 
de remoção de favelas ocorrido no Vetor Sudoeste e, encravadas nos morros da margem esquerda do Pinheiros, simbolizam toda uma vastidão periférica que se inicia a partir delas, em direção aos quadrantes sul e sudoeste da cidade, onde sucedem-se uma multiplicidade de bairros formados pelos ciclos de periferização da cidade ao longo das últimas décadas, nos quais vivem alguns milhões de indivíduos desde sempre privados de melhores condições e oportunidades de vida.

As favelas inseriram-se, em certo momento histórico, numa determinada lógica de expansão imobiliária da cidade e de barateamento, para o capital, dos custos de reprodução da força de trabalho. A maior parte delas, situadas em terrenos públicos e regiões altamente cobiçadas pela especulação imobiliária, foi paulatinamente arrancada, ao longo dos anos, do caminho por onde o grande capital fez a sua marcha em São Paulo. Não raro o poder público colocou-se ao lado do interesse privado e expulsou com violência os moradores de inúmeras favelas para as regiões mais periféricas da cidade e mesmo para outros municípios da região metropolitana. ${ }^{13}$ Às reformas saneadoras do início do século que visavam circunscrever e controlar as classes populares e higienizar a cidade, por meio do combate à disseminação das pestes atribuídas aos mais pobres, sobrepôs-se sem rodeios o puro e simples interesse econômico do capital imobiliário. Algumas gestões municipais da cidade de São Paulo nas últimas décadas reproduziram a velha imagem associada aos cortiços e habitações populares do início do século, pela qual as favelas eram vistas como uma anomalia do desenvolvimento urbano e um mal a ser extirpado. Por trás desta formulação ideológica, residiam as pressões do capital imobiliário pela desobstrução de regiões inteiras a serem redimensionadas, valorizadas e ocupadas por outros estratos sociais e por outras funções urbanas.

Fundada em meados dos anos de 1960, a favela da Peinha encontra-se assentada sobre terrenos público e privado, num morro no Jardim Santo Antônio, emoldurada pela Marginal Pinheiros e pela avenida João Dias. Tem como vizinhos o Centro Empresarial São Paulo, a empresa Origin do Brasil e o terminal de ônibus João Dias. Sua população, estimada em 2,5 mil pessoas divididas em 446 famílias, mora, em sua grande maioria, em casas de alvenaria construídas no sistema de autoconstrução (85\%), sendo que o restante possui barracos de madeira em áreas de risco de desabamento. A maior parte dos moradores é procedente de Minas Gerais, mas há uma pequena vertente nordestina, proveniente das zonas rurais de Pernambuco, Alagoas e Bahia. A grande maioria dos descendentes destes migrantes já é nascida em São Paulo. Em geral, seus moradores têm baixo grau de escolaridade e desempenham funções de pouca qualificação no mercado de trabalho.

Fundada também em meados dos anos de 1960, por trabalhadores migrantes que vieram a São Paulo para a construção do Estádio do Morumbi, a favela Real Parque encontra-se assentada em terreno público sobre um morro do subdistrito de mesmo nome, entre os bairros do Morumbi e do Brooklin, separados pela calha do rio Pinheiros. Tem como vizinhos um terreno desocupado, de propriedade da Eletropaulo, e diversos condomínios residenciais de alto padrão, situados no subdistrito vizinho de Paineiras do Morumbi. Sua população foi estimada, em 1994, em 7,5 mil pessoas. A maior parte de seus habitantes também mora em casas de alvenaria construídas no sistema de autoconstrução, embora ainda existam diversos barracos construídos com material precário, como madeira e papelão, e grande parte das moradias está situada em área de risco de desabamento. A maior parte dos moradores é formada por migrantes mineiros e nordestinos, mas seus descendentes são nascidos em São Paulo. O nível educacional e o padrão de qualificação profissional dos moradores é bastante semelhante ao dos moradores da favela da Peinha.

\section{O Vetor Sudoeste, pelos seus atores}

O que o senhor vai querer perguntar para um
homem pobre, analfabeto e feio como eu?
Sr. Valdomiro, morador da Favela Real Parque

Vivemos na era do capitalismo mundializado, de cunho financeiro e transnacional, cuja ma- 
nutenção recai sobre centenas de milhares de executivos ao redor do mundo que, por meio de seu trabalho cotidiano, realizam aquilo que se chama, genericamente, de globalização. Na cidade de São Paulo a maior concentração desses profissionais ocorre na região sudoeste.

Trabalhadores de alta qualificação, os gestores ou executivos das corporações transnacionais lidam com uma rotina de trabalho dominada por fluxos imateriais de capital. Estão envolvidos em atividades tão diversas como finanças, desenvolvimento de software, auditoria e consultoria empresarial, negócios jurídicos, mídia, publicidade, engenharia, arquitetura, administração da produção etc. Lidam com bens e serviços de produção e circulação mundial. Têm à sua disposição vasta gama de informações, variáveis e condicionantes para que realizem tomadas de decisões e se destacam aqueles que fazem uso destas ferramentas com mais inteligência e criatividade. Ao contrário das antigas chefias dos primórdios da industrialização ou dos funcionários de colarinho branco surgidos do aprofundamento da divisão social do trabalho na linha de produção, cujas funções eram controlar o ritmo do processo de trabalho, é da utilização ótima dos recursos informacionais e intelectuais que têm a disposição que os trabalhadores envolvidos na alta gestão das transnacionais movimentam a dinâmica de produção do valor nos dias de hoje. É de se supor que, para tanto, possuam habilidades em compreender e apreender novos conceitos e adaptar-se a novas situações, e que, por esta razão, ocupem o topo da pirâmide salarial.

O perfil educacional e socioeconômico que está se formando no interior das corporações presentes no Vetor Sudoeste e nas atividades de suporte a elas é significativamente diverso da média do restante da metrópole. O nível educacional dos funcionários empregados é bastante elevado, se comparado ao mercado de trabalho paulistano e brasileiro. ${ }^{14}$

O nível educacional dos nossos funcionários está dentro de uma média comparada às outras empresas de tecnologia. Mas no caso da Oracle, eu acho que 90 a 95\% das pessoas são graduadas; o nível é muito alto nesse aspecto, porque a operação precisa de pessoas com esse perfil. Existe também um número muito grande de pessoas pós-graduadas. Em todas as funções gerenciais para cima nem entra se não tiver graduação. Isso é pré-requisito (Érica Ramos, Gerente de Comunicações da Oracle).

Outra característica marcante do perfil educacional dos funcionários das corporações transnacionais que se instalam no Vetor Sudoeste da cidade é o conhecimento avançado de pelo menos uma língua estrangeira, preferencialmente a inglesa, considerada ferramenta corriqueira para as rotinas de trabalho.

O funcionário do ABN é jovem, de 20 a 29 anos, 90\% é graduado, alguns são pós-graduados. Aqui na Matriz, como são pessoas com cargos mais elevados, isso muda um pouco o perfil socioeconômico, que é mais alto. Pelo fato de o banco ser internacional, a maioria das pessoas que trabalham aqui tem pelo menos mais um idioma, que é o inglês, e, em alguns casos, é desejável o espanhol. Isso muda muito o perfil das pessoas que trabalham aqui, pois quando você vai selecionar o funcionário você leva em conta os idiomas...nem todos aqui, desde o boy até o presidente do banco, estão nesse nível. Mas pelo fato de termos mais cargos gerenciais do que operacionais aqui, o nível é mais elevado. E com relação ao perfil dos trabalhadores da região, talvez seja possível afirmar que haja semelhanças, pois não há fábricas nos arredores, e a vocação das empresas aqui é praticamente a mesma (Ruth Sampaio, Gerente de Recursos Humanos do ABN Amro Bank).

Os níveis de remuneração desses trabalhadores e seus efeitos em termos de poder aquisitivo são proporcionais tanto às responsabilidades que acumulam na gestão de grandes operações quanto à exigência crescente que as empresas fazem em termos de qualificação.

Eu diria que também noventa e tantos por cento das pessoas têm carro, têm apartamento, têm telefone. Se alguém fizesse uma pesquisa de poder aquisitivo, desse tipo de coisa, de aquisição de bens materiais, eu acho que a média seria muito elevada. Todo mundo faz viagem internacional, todo mundo fala uma segunda língua. O nível é muito alto (Érica Ramos, Gerente de Comunicações da Oracle). 
Nós temos um salário médio da ordem de 4.500 dólares mensais; eu diria que é um perfil acima da média, tanto para o mercado bancário quanto para o mercado em geral (Carlos Alberto Miranda, Vice-Presidente do Chase Manhattan Bank).

Desenvolve-se entre os funcionários das empresas da região sudoeste uma identidade corporativa, que não apenas atravessa as distinções nacionais e culturais mas parece inclusive ser mais forte do que elas.

O nosso funcionário tem acesso às tecnologias de ponta no que diz respeito à informática, que são suportes, ferramentas, e no que diz respeito a produtos e serviços internacionais. Nós comercializamos produtos e serviços internacionais. Todos nós temos acesso a isso, ou por estarmos trabalhando com esses produtos e serviços, ou através de treinamentos específicos sobre determinados produtos que estão disponíveis. Nós temos um sistema de e-mail com o qual falamos com o mundo inteiro em real time. Com todo mundo que é Chase people, Chase mundo, a gente fala (Carlos Alberto Miranda, Vice-Presidente do Chase Manhattan Bank).

A rotina cotidiana de trabalho nos escritórios é concebida a partir da operação global das corporações, a qual pressupõe um intenso contato entre profissionais oriundos dos mais diversos países, conforme mostram os depoimentos abaixo.

Eu, mais uma vez, acho que as empresas de tecnologia têm muito desse perfil, e a Oracle também se destaca nisso. Gerência para cima todo mundo faz pelo menos uma viagem a trabalho por ano. É essa coisa da integração, da interação com a operação mundial. A Oracle teve um processo forte de globalização há três ou quatro anos atrás. Hoje se você trabalha na área de suporte técnico e tem uma reunião da área de suporte técnico em Orlando, ou em San Francisco, ou onde quer que seja, se você tem aqui uma função específica que requer que você vá para lá, você vai com muita facilidade. Então, viagens internacionais para reuniões, para encontros, para eventos, isso é muito comum. Temos todo tipo de conexão, de comunicação para fora, através de internet, intranet, linha especial, linha dedicada, conexões de todo tipo, vídeo-conferência, equipamento para conference call, temos todos os recursos para se comunicar com o mundo... para nós é muito simples. E não podia ser diferente, a Oracle é uma empresa de tecnologia (Érica Ramos, Gerente de Comunicações da Oracle).

Temos um ambiente de trabalho moderno, fortemente informatizado, ligado em rede, nacional e internacionalmente. O contato com o mundo, viagens e contatos com estrangeiros são freqüentes. Há muito intercâmbio eletrônico de informações com as demais Andersens do mundo (Mark Nielsen, Diretor de Recursos Humanos da Andersen Consulting).

Temos aqui na região um escritório do banco para a América Latina e Caribe. As pessoas que trabalham lá ficam muito mais fora do país do que aqui. E ali circulam muitas pessoas de vários países todos os dias. Os contatos com o exterior são diários, daí o porquê da necessidade da língua. O contato é intenso, e o banco não sobreviveria sem ele (Ruth Sampaio, Gerente de Recursos Humanos do ABN Amro Bank).

Embora haja cotidianamente um contato tão pronunciado com pessoas originárias de várias regiões do mundo, cuja circulação na região sudoeste da cidade de São Paulo é cada vez maior, parece ser pouco comum aos profissionais que ali trabalham uma aproximação com outros grupos sociais que lhes sejam geograficamente próximos. O diálogo com a executiva da Oracle deixa transparecer o gradual distanciamento que está ocorrendo entre os setores do mercado de trabalho alocados nas grandes corporações e o restante da cidade, e, em especial, com os demais contingentes presentes na sua porção sudoeste.

P: Tem uma vida pública na rua, mas as pessoas usam o passeio público ou ficam no escritório o tempo todo? As pessoas andam na rua, interagem, vêem pessoas de outros níveis?

R: Acho que pouco. Acho que aqui lembra um pouco o jeitão americano mesmo: grandes empresas, com grandes pátios de estacionamento, as pessoas entram e passam os seus dias inteiros aqui. Eu diria que você gasta alguns minutos indo almoçar, nada mais que isso. Não é como uma avenida Paulista, onde se tem um ambiente externo grande, diversificado... aqui não. Mas quando você anda, é um perfil muito alto. Todo mundo tem o mesmo perfil. É outro universo. Mesmo eu 
que estou aqui há muito tempo, estranho quando ando em outro lugar, como na Paulista, eu me sinto totalmente desconfortável. Porque aqui é um perfil único mesmo.

Carlos Alberto Miranda, Vice-Presidente do Chase, concorda: "Sim, tem um pouco isso de sair na rua, mas é uma coisa pequena. O cara anda 150, 200 metros, e volta.

Há problemas infra-estruturais na região que, se não impedem, dificultam em muito o uso do passeio público pelos executivos que ali trabalham. Não houve, ao longo do tempo, a criação de uma infra-estrutura urbana minimamente agradável para um uso da via pública que não o dos automóveis. "A praça, enquanto lugar público em que se enfrentam formas de sociabilidade antagônicas, é o cenário de exorcização das diferenças sociais por meio do sentimento comunitário, portanto, palco privilegiado para a exibição dos conflitos e seu enfrentamento através da palavra, dos gestos e posturas corporais. Ao esvaziamento da praça corresponderá um silêncio das vozes" (Andrade, 1997).

Existe um pouco de trotoir, mas é pouco, porque o espaço é completamente inadequado para isso. As calçadas e as ruas não foram projetadas para esse tipo de coisa. As poucas praças que existem por aqui são anteriores ao desenvolvimento da região e não foram pensadas para essa função. As ruas não têm tamanho para comportar o número de carros que afluem para a região e o caos no trânsito é enorme aqui (João Marcelo R. Saraiva, Consultor da Watson Wyatt).

Além das dificuldades práticas para o uso do espaço público, aflora nos depoimentos dos executivos a questão da criminalidade, permeada pela visão que associa espaço público e violência.

Esta é uma região relativamente tranqüila. Aqui é curioso que você não tem talvez aquele movimento típico da avenida Paulista, os pequenos roubos, os assaltos, porque lá é um número muito maior de pessoas, porque o perfil é mais diversificado... mas aqui você tem grandes roubos, grandes assaltos em que matam pessoas na porta do Carrefour, ou assaltos a banco ali na esquina, em que matam dois vigias no carro forte. Você tem um outro tipo de violência. Não é aquela violência típica do roubo da carteira, mas são coisas mais pesadas. Aqui a gente fica sabendo de grandes coisas. É engraçado, aqui, quando a gente fica sabendo, são grandes assaltos, ação de quadrilhas. Eu acho que até em função do perfil que tem nessa região. $\mathrm{O}$ perfil de assalto é outro. Eu já presenciei vários. Vem helicópteros. A questão da segurança aqui não vai para o cidadão comum, mas para a própria segurança das empresas (Érica Ramos, Gerente de Comunicações da Oracle).

Na região podem haver eventuais arrombamentos de carros. O que dá medo aqui é que a noite as ruas são extremamente escuras, o bairro é muito deserto, todos os pontos comerciais fecham após as 18h00. Mas o bairro, durante o período diurno, é bem mais tranqüilo do que o Centro ou a Paulista (Ruth Sampaio, Gerente de Recursos Humanos do ABN Amro Bank).

A questão do aumento da criminalidade violenta na região é vista, no entanto, como uma questão de tempo. Circundados por uma realidade social na qual a violência adquire características quase epidêmicas, a tendência é que os funcionários corporativos, tomados por uma sensação de que estão sendo sitiados pelo ambiente externo, se fechem cada vez mais dentro de suas torres de escritórios.

Aqui é um lugar tranqüilo. Aqui é bem mais seguro do que a Paulista. Agora, se você sobe mais 1000 metros e esbarra na avenida Santo Amaro, você passa a ter todos esses tipos de problemas. O corredor de trânsito e o fluxo de pessoas aqui ainda não suscitou esse tipo de violência, mas eu acredito que isso vai ser uma questão de tempo. A região vai passar a ser alvo deste tipo de ocorrência, naturalmente. A violência é gerada por um desnível econômico e social muito forte. Essas pessoas que estão fazendo a violência estão tentando sobreviver de alguma forma, ganhar o dinheiro delas de alguma forma, e na hora que a coisa começa a ficar mais difícil de se fazer isso lá na Paulista, ou na avenida Santo Amaro, eles vão ver o que é mais fácil. Mas vai ser na rua isso, não dentro do prédio, vai ser no passeio público (Carlos Alberto Miranda, Vice-Presidente do Chase Manhattan Bank).

Enquanto em alguns depoimentos se reconhece a desigualdade social e econômica acentuada que caracteriza a realidade brasileira, outras falas parecem reduzir toda a questão da proximida- 
de física de contingentes tão díspares entre si a uma questão praticamente naturalizada, a qual pode ser evitada com o reforço dos aparatos de segurança.

Não vemos nenhum problema. Nunca tivemos nenhum problema aqui. Temos uma equipe e um sistema de segurança muito eficazes. Essa é uma questão social, com a qual temos de conviver. Essa realidade não nos prejudica de forma alguma (Gabriela Andrade, Gerente de Marketing do World Trade Center).

Atravessa também os depoimentos dos funcionários corporativos certa desesperança em relação à mudança deste estado de coisas, desta disparidade aguda que é vista e reconhecida, ainda que a experiência cotidiana dessas pessoas esteja cada vez mais influenciada pelos condicionantes globais. As falas dos executivos das transnacionais não exprimem propriamente um desprezo em relação aos mais pobres que moram em favelas ao alcance de seus olhos através das janelas dos escritórios em que trabalham. Numa cidade como São Paulo não se pode deixar de perceber a pobreza. Mas as falas denotam certa descrença em relação à solução do problema, à superação de uma característica tão forte da nossa conformação social. Talvez denotem simplesmente indiferença. Como afirmou Milton Santos, os fragmentos resultantes do processo de mundialização articulam-se segundo lógicas duplamente estranhas: por sua sede longínqua, distante do espaço da ação, e pela sua inconformidade com o sentido preexistente da vida na área em que se instala, produzindo uma verdadeira alienação territorial (Santos, 2000). O executivo da Birmann utiliza a metáfora do conquistador inglês na Índia, imortalizada em filmes clássicos, para fazer referência não propriamente à pretensa e discutível missão civilizatória dos colonizadores britânicos no Oriente, mas sim para aludir à extrema disparidade de condições socioeconômicas entre uma elite reduzida cercada de pobreza por todos os lados, tão visível nas telas de cinema quanto nas ruas de São Paulo.

Nós que vivemos em São Paulo vivemos dessa maneira. Somos mais ou menos como o conquis- tador inglês que vivia na Índia. Esse é o nosso presente. E não há nada que diga que essa situação vá mudar no futuro. Isso deve se aprofundar. Há um mecanismo que traz esse pessoal mais pobre para um nível de consumo mais aceitável. Mas a dinâmica contrária é muito maior. Não há nada nos três níveis de governo ou da iniciativa privada, em termos de iniciativas, que apontem para a mudança dessa situação (Ricardo Pinheiro, Diretor de Projetos da Birmann).

Diante do insulamento dos funcionários corporativos nas torres de escritórios e do aumento da criminalidade violenta que é atribuída à proximidade espacial de populações tão distintas em termos socioeconômicos, especula-se que o capital possa, uma vez mais, reproduzir seu padrão de crescimento territorial na cidade e eventualmente expulsar para regiões longínquas as populações pobres que ainda habitam as proximidades das sedes das corporações. Talvez possa mais do que expulsar, deslocando essas populações para "mais longe".

Eu tenho medo que essas pessoas excluídas sejam ainda expulsas para lugares mais longínquos. Veja o exemplo da Águas Espraiadas. Tiveram poder de tirar aquelas pessoas de lá e tiraram. Não acho que os pobres possam invadir nossa região, mas que nós tenhamos poder de invadir, crescer e jogar essas populações ainda mais para longe. E eu não sei onde é esse mais longe (Ruth Sampaio, Gerente de Recursos Humanos do ABN Amro Bank).

Do receio à indiferença, e da indiferença à barbárie, pode ser um passo. Como bem diz Viviane Forrester em O Horror Econômico, "já não ignoramos, não podemos ignorar que ao horror nada é impossível, que não há limites para as decisões humanas. Da exploração à exclusão, da exclusão à eliminação, ou até mesmo a algumas inéditas explorações desastrosas, será que essa seqüência é impensável?" (Forrester, 1997). Talvez aí resida o caráter de funcionalidade da tragédia humana que tem atingido tão fortemente a outra margem do rio. ${ }^{15}$

Você está vendo como os jovens estão se acabando? Sempre, sempre nós vai em velório. Velório de pessoas amigas que moram por aqui. A gente 
que ainda não morreu ainda vai no velório dos outros. Eu não sei se você pensa como eu penso, ou se você vê o que eu vejo, mas faz dó, rapaz. A gente vai no velório de alguém, no enterro de alguém, de cada vinte pessoas que são sepultadas por dia, de cada vinte, quinze é jovem. E isso é todos os dias, uma rotina, todos os dias (Valdomiro Lima da Silva, Morador da Favela Real Parque).

Valdomiro, assim como inúmeros outros moradores das favelas Real Parque e Peinha, é um migrante, que se instalou em São Paulo entre fins dos anos de 1960 e início dos de 1970. Traz em sua fala um gosto amargo, que muitas vezes não é corroborado por outros indivíduos que vieram para a metrópole na mesma situação que ele.

Eu sou, como diz, muito feliz em São Paulo. Mas também tenho muitas guerra que eu já passei. São Paulo é um lugar muito bom, lugar de pessoa que sabendo levar a vida, ela vive. Mas sobre a violência, também é demais. A gente pensa que tem justiça, mas não tem justiça. [...0 Tem violência, você vê aí, essa mortandade. Eu mesma perdi um filho, meu filho não era bandido, nem marginal, menino trabalhador, menino honesto. Morreu com 25 anos, não teve nenhuma sujeira em computador nenhum. Perdi uma filha com 28 anos. Agora tá fazendo nove meses que mataram um neto meu com 19 anos. Ele era segurança aqui do prédio. Então eu sou uma pessoa muito revoltada. Mas só que eu fiz muitos amigos aqui, que me ajudou, como esse meu marido Antônio. São Paulo foi ótima, graças a Deus (D. Maria do Socorro Pereira, moradora da Favela da Peinha).

$\mathrm{Na}$ maioria das vezes relegadas a uma condição menor pelo poder público, foi na sociabilidade desenvolvida entre iguais, em relações de ajuda mútua, que as populações pobres de São Paulo criaram noções de pertencimento no espaço metropolitano e deram sentido às suas vidas. Conseguiram trabalho, constituíram família e conquistaram um lugar no mundo. "E foi por esse viés citadino de pertença à vida urbana, mesmo fora da esfera da participação política, que a população encontrou o caminho para fazer valer seus interesses pela cidade. Tecendo uma rede de auto-ajuda e formas de sobrevivência nos poros da cidade, a população excluída fez do que lhe restou da cidade um mundo de arrimo às suas necessidades, numa referência de suas práticas, onde cabia até mesmo o devaneio, o sonho de uma feliz - cidade" (Pechman, 1997).

São Paulo toda vida pra mim foi boa. Tem mais vantagens do que a própria minha terra. Porque se a minha terra fosse boa eu tava lá. A minha terra é muito difícil, muito escassa as coisas (D. Luíza dos Santos, moradora da Favela Real Parque).

É importante notar que a experiência de vida em São Paulo foi boa, como diz Luíza, ou ótima, como quer, apesar de tudo, Maria do Socorro. Mas é situada no passado. De fato, para os migrantes, São Paulo foi boa porque na metrópole eles puderam, segundo sua ótica, experimentar algum grau de mobilidade social, ter acesso a bens e oportunidades com as quais seus antepassados jamais puderam sonhar e, talvez, até mesmo vencer na vida. Esta noção de realização e êxito guarda relação com o referencial existencial original. Relativamente à situação social nos locais de nascimento, pode-se dizer que a longa trajetória que envolveu a viagem até São Paulo, o estabelecimento na cidade por meio da obtenção de um lugar para morar e um trabalho de onde tirar o sustento, a identificação com este trabalho, o aprendizado de novos códigos de conduta, a formação de relações sociais de ajuda mútua, a constituição de uma família na cidade, o sentimento de ajudar a construir a cidade, a afetividade daí decorrente resultaram, finalmente, na idéia de conquista de um lugar no mundo. Mas que se retenha a idéia de que São Paulo foi boa para as populações que para ela migraram e nela se estabeleceram, conquistando o seu lugar. Será que ainda continuaria a sê-lo?

Quando a gente chegou aqui, tinha muito emprego. Mas de três anos pra cá São Paulo fracassou. Quando nós viemos pra cá tinha emprego demais da conta. Só não trabalhava quem não quisesse trabalhar. Vinham buscar o pessoal em casa pra trabalhar. Agora é que tá desse jeito aí. Nós já vimos o que passamos na vida nossa. Agora, essa criançada que está aí agora, se Deus não por a mão pra ver, como é que vai ser essa criançada, essa rapaziada nova, como é que vai ser? Não pode comer porque não tem serviço mais? Não 
pode ninguém trabalhar então? (Sr. Antônio, morador da Favela da Peinha).

Parece estar em vias de extinção a civilização do trabalho, fundada nas relações contratuais decorrentes de décadas de luta das classes trabalhadoras em todo o mundo, cuja maior característica era o potencial para integrar milhões de indivíduos.

Olha, pensando bem, eu não sei nem como analisar. Eu não sei nem o que falar. Eu não sei nem entender como a maioria do povo vive. Tem pessoas aqui que é trabalhador mesmo. Mulheres e homens, são trabalhador mesmo. Mas não tem aonde trabalhar, não consegue trabalhar. E tá vivendo. Agora, como, meu amigo, eu não sei. $\mathrm{O}$ campo de serviço, a faixa de emprego, a oportunidade para viver com o suor do próprio rosto, ninguém tá dando pra ninguém. A gente tá vivendo pela misericórdia de Deus (Valdomiro, morador da Favela Real Parque).

Está em curso um processo de alterações profundas na existência material e na subjetividade dos pobres. Os grupos sociais menos privilegiados são os mais atingidos pela dinâmica econômica que assola uma metrópole como São Paulo e vivem hoje um sentimento de desilusão diante da distância que se aprofunda entre os anúncios e as possibilidades oferecidas pela cidade. Se a industrialização dos anos de 1950 em diante significou a chance, para milhões de brasileiros, de melhorar de vida através da migração para a metrópole e, bem ou mal, a integração num universo material e simbólico marcado pelas idéias de crescimento, progresso e oportunidades para todos, os desdobramentos socioeconômicos que se abatem sobre a maior cidade do país só podem significar, neste momento, um sentimento de desencanto, de decepção, de traição. Nas palavras de Valdomiro:

No sentido de favorecer a vida do pobre, do trabalhador, a coisa complicou. Então, quer que eu diga como tá São Paulo agora? Agora? Uma droga. Todo mundo inseguro, meu irmão. Vive todo mundo inseguro. Agora não tem mais em quem acreditar. Não se sabe se acredita em governo... os governos atuais, prefeitos atuais, até mesmo na polícia.
Como acreditar? Não tem mais como acreditar. Então para mim está uma droga. Piorou. Recursos? Recursos para o pobre viver aqui? Aqui no sul do país, na grande cidade brasileira, tem mais pobre do que nas cidades mais pobres do Nordeste. No Nordeste o cara ganha dois reais por dia, três reais, mas sobrevive. Aqui as vezes o cara consegue ganhar vinte reais, mas ele é obrigado a gastar trinta com as explorações, de farmácia, de mercado, tudo. Aqui se paga pra tudo. Então não tem como. Não se vê o lado dos pobres. Muitos nordestinos, muitos da gente está aqui de teimoso, porque não pode voltar para as suas terras. Desfez o que tinha lá, confiando em São Paulo, confiando no sul do país, confiando nos governos de São Paulo, deixando o que tinha lá... ou as vezes os mais ricos tomaram dos mais pobres o que eles tinham lá. Veio parar aqui, o pobre veio parar aqui. Agora tá lascado, porque agora nem aqui, nem lá (Valdomiro, morador da Favela Real Parque).

Após anos enfrentando as dificuldades de integração a uma realidade completamente nova, pela qual tiveram de abandonar boa parte das referências que balizavam suas condutas, adquirir novas habilidades e tecer novas relações para incorporar-se à vida metropolitana, os mais pobres, em especial os migrantes, sofrem as conseqüências da desarticulação do principal instrumento de formação de uma teia de relações sociais que permite a integração à sociedade: o trabalho. O desemprego que se abate sobre os contingentes de migrantes que há décadas mudaram-se para São Paulo, e na cidade puderam estabelecer uma existência social relativamente sólida, embora sempre permeada de dificuldades, provoca perplexidade entre os indivíduos afetados, pervertendo o sentido que estes davam às suas trajetórias de vida. Em suma, a crise que se instala hoje sobre as populações pauperizadas põe em xeque o lugar que elas ocupam no mundo. Como afirma Ianni, "é principalmente nas grandes cidades, metrópoles, megalópoles e, freqüentemente, nas cidades globais, que se localiza a subclasse: uma categoria de indivíduos, famílias, membros das mais diversas etnias e migrantes, que se encontram na condição de empregados mais ou menos permanentes" (Ianni, 1996).

Desmobilizados politicamente, mesmo vivendo na periferia da zona sul de São Paulo, uma das regiões mais efervescentes, nos anos de dita- 


\section{IMPACTOS DA MUNDIALIZAÇÃO SOBRE UMA METRÓPOLE PERIFÉRICA $\mathbf{6 1}$}

dura militar e abertura política, em termos de mobilização política popular, os moradores das favelas Peinha e Real Parque encontram-se impossibilitados, em razão da falta de renda oriunda do desemprego, de transitar pelo espaço urbano mais amplo. É comum nos dias de hoje se deparar com dezenas ou centenas de adultos, em dias úteis ou não, ociosos dentro de seus barracos. A cidade transforma sua vocação econômica e sua paisagem e tudo o que os favelados conseguem exprimir é estranhamento diante do que vêem.

Eu saio pouco daqui. Saio pouco. Mas às vezes eu tenho que resolver umas coisinhas minhas, lá no centro, e então eu vou. Teve uma época, uns tempos atrás, eu passei três meses sem ir à cidade. Aí eu peguei um ônibus pra ir lá no centro e eu fui lá no centro. Nós aqui nós pega essa avenida Santo Amaro quase toda. Ó, rapaz, faz dó, viu? Porque eu conheci no decorrer dessa avenida Santo Amaro, tanto de um lado como do outro, direita e esquerda, cheio de lojinhas, fabriquinhas, bares, que há cinco, seis, oito, dez anos atrás, funcionavam bonitinho, todo mundo fazia seus movimentos. Hoje em dia você anda lá, tá tudo fechado. Fechado. As portas tudo fechadas. Pichadas. A placa "aluga-se", "aluga-se", "vende-se". E ninguém se arrisca a alugar nada. É movimento zero (Valdomiro, morador da Favela Real Parque).

Como afirmou Kevin Lynch (1960), a cidade é o suporte material da memória. Mas Valdomiro já não consegue reconhecer no espaço construído a cidade que conheceu anos atrás. Busca resgatar os signos de um tempo em que a metrópole dava chances a todos, ou a quase todos, através da efervescência das atividades econômicas, tanto as mais complexas como, e principalmente, as mais simples, como as lojinhas e fabriquinhas que funcionavam "direitinho", conferindo vigor e movimento à cidade, abrindo oportunidades e integrando indivíduos. Ele se utiliza dos fragmentos da lembrança de outros tempos e tenta ressignificar a realidade urbana, ressaltando a infinidade de placas de aluguel e venda de imóveis que viu pela avenida Santo Amaro, e arrematando com a metáfora tão comum a trabalhadores como ele: "é movimento zero".

Possivelmente pelo fato de constituírem realidade ainda nova, os prédios da Marginal Pinheiros são vistos pelos moradores das favelas, mas não são reconhecidos, identificados ou capturados por elaborações mentais que possam lhe atribuir gama muito variada de significados, pelo menos até o momento. A única percepção mais consolidada é aquela imediata, que aponta para a hierarquização do espaço urbano. O diálogo com Valdomiro ilustra a sensação de pouca familiaridade diante da nova cidade que está se construindo bem em frente à sua janela. Na impossibilidade de fazer uso de referências novas para compreender o que significa sua nova vizinhança, Valdomiro serve-se da explicação da exploração da força de trabalho empregada na construção das torres para conferir significado ao que vê.

P: A cidade está mudando muito. Muitas fábricas foram embora, existe muito desemprego, muitos prédios de escritórios estão chegando... por exemplo, aqui na nossa frente há todos esses prédios, o que será que a gente pode esperar disso? R: Eu acho que para o pobre, para a classe do médio ao pobre, quanto mais cresce a cidade, quanto mais se embeleza a cidade, quanto mais pintam os prédios, é mais miséria pra gente. Mais miséria para o pobre. Porque pra fazer um prédio desse, eu sei, eu que sou carpinteiro, eu sei o que é a construção civil porque eu sou carpinteiro, eu ajudei a construir muitos prédios aqui dentro da favela, enfim, que hoje tá aí. Pra fazer um prédio desses, se os donos quiser, eles faz dentro de um ano, um prédio de vinte, vinte e cinco, trinta andares. A covardia está tanta, a lei está tão fajuta, tem empresário aí que faz um prédio de trinta andares dentro de um ano com os trabalhadores tudo clandestinos. Tudo clandestino. Com um ano o prédio está pronto. Ninguém recebeu direito trabalhista, a miséria do trabalhador continua e os empresários é quem tá beneficiado. Só.

D. Luíza, por sua vez, vê na construção das torres uma séria ameaça à permanência das populações de baixa renda nos entornos da Marginal. Talvez a experiência traumática de ter presenciado a retirada das favelas que existiam sobre o leito do córrego Águas Espraiadas, localizadas ao lado do que hoje são o Centro Empresarial Nações Unidas e a sede da Rede Globo, seja o motivo mais forte que confere significação, aos olhos dela, para a vizinhança opulenta que se instala também diante da janela de sua casa. 
Isso tudo aí era terreno vazio e favela. Isso dá um pouco de medo, porque o pessoal já fica cismado com os prédios, né? Porque o rico pra tirar o pobre é daqui pra ali. Então eles vai apertando com os prédios, né, e pra onde vai os pobres? (D. Luíza dos Santos, moradora da Favela Real Parque).

Em determinados trechos da Marginal Pinheiros a imagem de grandes prédios envidraçados não dialoga com o restante do ambiente construído, como no caso do edifício sede da Microsoft, localizado numa região ainda pouco verticalizada, ao lado da Ponte João Dias e de frente para a Favela da Peinha. Há um isolamento concreto entre o prédio e seu entorno que provoca um choque visual entre a torre e o restante do que pode ser captado pelo ângulo visual. Em outros trechos da avenida, notadamente na Chácara Santo Antônio e na região da Berrini, já bem mais edificadas, as torres se perfilam em número significativo, constituindo propriamente a imagem de uma outra cidade, encravada dentro da cidade. As combinações inusitadas entre granito, alumínio e vidro, as formas diagonais, cilíndricas, longitudinais e as reentrâncias que compõem a estética desses prédios parecem fazer uma permanente homenagem a si mesmas, demarcar uma ruptura com o tempo histórico e com o espaço geográfico, ignorar tanto o entorno construído quanto a dinâmica social exterior e isolar os prédios e seus freqüentadores em si mesmos, através das paredes de vidro externas, que tão bem refletem o leito do Pinheiros como espelham quem tenta invadi-las com o olhar. ${ }^{16}$

Ao contrário da São Paulo dos mil prédios, de um Copan ou de um Edifício Itália, por exemplo, que com suas dimensões generosas pareciam querer dizer para a cidade o quão capazes éramos em ser a locomotiva do país, a capital do progresso, a cidade que não podia parar, as novíssimas torres de escritórios do Vetor Sudoeste parecem querer demarcar, através da linguagem de suas formas, o quão diferentes são do restante da cidade. Ao contrário da estética portentosa representada na verticalidade fálica do mar de prédios, que caracterizava e tanto orgulhava a metrópole nos anos 1960 e 1970, e que afinal possuía uma função integradora da imagem da cidade, a parede de torres de escritórios que se forma à margem direita do Pinheiros dá ares de não querer estabelecer diálogo com o restante do espaço urbano. Não tem a pretensão de ser orgulho para ninguém (a não ser para seus incorporadores, construtores e proprietários, obviamente). Com efeito, uma única torre, como no caso da localizada ao lado da Ponte João Dias, já é suficiente para demarcar as distinções em relação às cercanias. ${ }^{17}$

Daí talvez a dificuldade manifestada pelos moradores do outro lado do rio em compreender aquilo que se modifica tão rapidamente bem diante dos seus olhos. A estética que o horizonte da cidade adquire pode ser tão incompreensível quanto as transformações do modo de acumulação que se processa, neste mesmo espaço urbano, nos últimos anos. Para Valdomiro, os prédios significam maior grau de exploração da mão-de-obra barata, farta como nunca na cidade. Para D. Luíza, representam a expulsão física da população pobre da região para locais ignorados, desfazendo suas teias de sociabilidade e desmantelando seus meios de ganhar a vida. O desenvolvimento recente dos circuitos de valorização do capital na cidade, todavia, podem indicar uma terceira opção, possivelmente pior do que as manifestadas por Valdomiro e Luíza: a negação do acesso dessas populações à economia formal e aos direitos de cidadania. Não propriamente o aprofundamento da exploração a que estiveram submetidos durante anos, e que foi funcional em determinado momento do desenvolvimento econômico da cidade e do país, e tampouco a expulsão para rincões periféricos, dada a própria lógica da urbanização de favelas levada a cabo em São Paulo desde 1992. Mas sim a morte civil desses contingentes, desprezados pelo capital e servindo, na avenida de maior circulação da metrópole, apenas como moldura visual de uma cidade supostamente harmônica.

\section{Expectativas para o futuro}

As investidas realizadas pelo grande capital, associado a uma certa concepção histórica de intervenção do Estado sobre o espaço público, são vistas como as causas do aprofundamento das diferenças econômicas e distâncias materiais e sim- 
bólicas entre os vários estratos sociais presentes na cidade. O acirramento das desigualdades, a explosão da violência, a queda brutal de qualidade de vida, inclusive para os segmentos sociais mais elevados, são todos fatores apontados como resultantes da lógica que preside tanto a dinâmica econômica atual, quanto o modo de se construir a cidade e a própria postura dos estratos que evitam ou mesmo abandonam a intermediação pública para a resolução dos conflitos.

Acho que as pessoas ou os poderes que estão construindo esse mundo bem moderno aqui na frente deixa de lado a vizinhança; por não ter contato, acho que eles vão sair perdendo. O que mudou em São Paulo é que nem para rico São Paulo é hoje uma cidade mais tranqüila. Antigamente acho que era. Nem segurança vai conseguir manter quando esses mundos ficam tão distantes. Acho que um dia vai ter conflito (Rudolf, da Associação Comunitária Monte Azul).

Vejo com pesar o destino que São Paulo está tomando. Se, de um lado, São Paulo é uma cidade de diferenças que já abrigou raças e credos diversos, e por causa disso cresceu e se enriqueceu como metrópole, por essa própria razão pode estar se acabando. Isto porque acho que São Paulo sente direta e intensamente o acirramento de todas as diferenças socioeconômicas e culturais existentes no país. E isto faz com que a distância entre as pessoas de cada classe ou realidade cada vez aumente, com globalização versus marginalização, tornando muito difícil a convivência pacífica. Conflituosidade e indiferença já são características presentes, mas podem ser mitigadas pelas iniciativas já existentes que visam promover maior cooperação e aproximação, defesa de direitos e de qualidade de vida, com movimentos de bairro, de cidadania... é rezar e esperar!... (Patrícia Carvalho, Assistente Senior Marketing do BEAL).

Valdomiro, morador da Favela Real Parque, revela seu sonho:

P: Seu Valdomiro, o senhor tem algum sonho de vida, que o senhor espera, o que o senhor espera pra daqui a dez anos, pra vida do senhor e pra vida do pessoal aqui?

R: Em primeiro lugar, eu queria que mudassem as leis do nosso país. Que nós tivéssemos governos, autoridades mais sérias, que tivessem mais respei- to com a nação. Que cumprissem o que eles prometem. Que chegasse ao conhecimento deles a necessidade de cada brasileiro, de cada pai de família, de cada mãe de família, e da juventude, que eles dizem e sabem que é o progresso do país. Essa juventude aí, ela é uma horta. Mas o dono tem que zelar da horta. Se não zelar a lagarta vai lá e come tudo. Acaba. E quem é o dono dessa horta? Não é as autoridades? Não é o senhor presidente, não é os senhores governo, não é os senhores juizes? Não é esse povo? Então eles têm que cuidar da horta, porque senão o caruncho come. E o que é o caruncho? O que é o inseto que tá querendo devorar a horta? É a falta de cultura, que os jovens não vão ter...do jeito que vai, não vão ter; hoje em dia quem tem a oitava série, simplesmente a oitava série, é um analfabeto, é considerado ainda um analfabeto. Não é verdade? Então esse povo tem que abrir campo, abrir campo de estudo, de educação. E também nem só a educação, como outros cuidados. Cuidados com moradia, dignidade, segurança para o jovem. Você está vendo como os jovens estão se acabando? Sempre, sempre nós vai em velório. Velório de pessoas amigas que moram por aqui. A gente que ainda não morreu ainda vai no velório dos outros. Eu não sei se você pensa como eu penso, ou se você vê o que eu vejo, mas faz dó, rapaz. A gente vai no velório de alguém, no enterro de alguém, de cada vinte pessoas que são sepultadas por dia, de cada vinte, quinze é jovem. E isso é todos os dias, uma rotina, todos os dias. Agora, por que isso? Falta de segurança para a nação. Falta de educação para os jovens, falta de autoridade para combater o tráfico de drogas, combater as drogas. Combater a prostituição. Ninguém vê nada, ninguém vê nada, meu amigo. E se as autoridades não tomar uma providência sobre isso á́... ai dos seus filhos, coitado do futuro dos seus filhos, e também dos filhos deles também.

Faço do sonho de Valdomiro, homem "feio, pobre e analfabeto", como ele mesmo se definiu quando de nosso primeiro contato, o sonho de milhões de brasileiros que vivem cotidianamente a experiência da separação material e simbólica de um mundo que fazia sentido até outro dia, e que se recusam, através dos apelos a formulação de uma regulação social pública, a serem reduzidos ao papel de párias. Eis o homem de escolaridade pouca e de oportunidades de vida tão radicalmente estreitas que utiliza as lembranças da infância rural para 
metaforizar a sociedade e dar sua explicação sobre o mundo. Que o caruncho da privatização das relações sociais não destrua a horta de Valdomiro. Que não destrua a horta de todos nós.

\section{Conclusão}

O desenvolvimento recente do bairro globalizado na região sudoeste da cidade de São Paulo demonstra a prevalência de um capital que crescentemente se mundializa, atravessa fronteiras territoriais, serve-se do Estado para maximizar a sua valorização e ignora parte significativa dos entornos geográficos e sociais. Desenvolve laços de sociabilidade que parecem ser mais fortes entre seus componentes, interligados em redes informacionais, do que propriamente com atores e grupos sociais que the são distintos.

O processo de mundialização do capital transfigura as espacialidades ao redor do mundo e redefine a morfologia das metrópoles. Se a metrópole clássica, tal qual a conhecemos nos escritos de um Engels, de um Dickens, de um Benjamin ou na poesia de Baudelaire, era vinculada aos processos de modernização, tendo a dimensão do trabalho industrial como organizadora de uma economia, de uma sociabilidade e de uma estética próprias, as metrópoles contemporâneas, sejam as do países do núcleo do capitalismo mundial ou não, com suas ilhas de globalidade e suas subversões às dimensões de tempo e espaço, significam o fim de uma regulação política da dinâmica social, ou, na melhor das hipóteses, significam a redução radical da capacidade regulatória do Estado, voltado ao atendimento das demandas de apenas alguns grupos e espaços urbanos, notadamente os mais mundializados.

A volatilidade crescente do capital solapa as vontades reguladoras do planejamento urbano, desmantela as reivindicações de inúmeros grupos sociais presentes na cidade e, no limite, pode impossibilitar a construção de uma sociedade plausível. O Estado, assumindo apenas o papel de gerente das necessidades do grande capital, refuta a idéia de uma reelaboração da dimensão política e ignora as demandas da maioria da população urbana. Como nos diz Rancière, daí decorre o desen- tendimento (1996). Logo, àqueles que não têm suas demandas reconhecidas só resta lutar para conquistar o reconhecimento de seus pleitos, de suas falas, de seus discursos, fundando no conflito a sua reivindicação, fazendo os grupos privilegiados os reconhecerem como sujeitos de direitos e obrigando o Estado a se repolitizar e se abrir ao diálogo. Enquanto as condições sociais objetivas para tanto não se tornam realidade, o que se observa nas grandes cidades do mundo é que a fala das populações desprivilegiadas tem se dado através de gritos, numa tentativa desorganizada de fazer valer os reclamos das maiorias. No caso de São Paulo, a explosão da violência, antes restrita aos circuitos periféricos e atualmente generalizada pelo espaço urbano e transbordando para dentro inclusive da ilha de globalidade representada pelo Vetor Sudoeste, ilustra a dimensão da gravidade da adoção de uma estratégia de preparar um pequeno recorte da cidade para ter competitividade internacional e ignorar todo o restante. A questão de fundo é: até que ponto a construção de um enclave, pelo capital privado e pelo Estado, é eficaz em manter tal espaço asséptico e imune à violência, à pobreza, à decadência econômica e ao abandono que se passam fora dele? Ou, extrapolando a questão ao plano nacional, até que ponto o desenvolvimento brasileiro vai poder continuar se dando aos saltos, sempre a adentrar em novos ciclos de inserção internacional sem, no entanto, resolver os desequilíbrios criados pelos ciclos anteriores?

Pode-se dizer que, em todos os ciclos pelos quais passou a cidade ocidental, da antiga cidade mercantil à cidade industrial, a mais marcante característica urbana sempre foi o encontro de uma gama de atividades econômicas diversas, empreendidas por indivíduos os mais variados, envolvidos num conjunto de trocas que constituem o cerne da sociabilidade. Hoje, no entanto, é possível que, diante tanto das revoluções tecnológicas em curso, que ensejam a explosão de processos imateriais de valorização do capital e virtualização do espaço, quanto do afastamento progressivo, no espaço urbano, entre grupos sociais diferentemente relacionados com os fluxos globais de capital que atravessam o mundo, estejamos assistindo à implosão do conceito clássico de metrópole. 


\section{IMPACTOS DA MUNDIALIZAÇÃO SOBRE UMA METRÓPOLE PERIFÉRICA $\mathbf{6 5}$}

Em cada período histórico, caracterizado por suas técnicas e tecnologias próprias, existe um tipo específico de uso e interação com o espaço. Numa época em que a cidade deixa de ser industrial e passa a ser atravessada por inúmeros fluxos imateriais, é possível que a relação com o espaço se torne virtual, pelo menos para aqueles indivíduos e grupos sociais mais diretamente envolvidos com a mundialização do capital. Este pode ser o caso dos executivos das transnacionais, permanentemente conectados ao mundo através das tecnologias de informação cuja experiência social cotidiana é crescentemente desmaterializada. Sob esta perspectiva, poderíamos dizer que esses estratos não vivem mais a cidade. Pois viver a cidade, tal qual a vive o flâneur, por exemplo, é andar pelo passeio público, é deslocar o corpo no espaço, é interagir, conhecer e reconhecer o outro, exercitar e desenvolver identidades a partir do encontro com o diverso, apreender a materialidade urbana e criar noções de pertencimento. ${ }^{18}$

Se os indivíduos já não compartilham esta experiência, e vivem muito mais a deslocar-se pelos espaços virtuais ou reais das torres de escritórios, ou se vivem reduzidos a circunscrições urbanas diminutas, por ocasião de estarem sendo descartados pelos processos de acumulação, o que temos é a desconstrução de nossas metrópoles, ou, pelo menos, do clássico conceito que as define. Mais correto, talvez, seria chamá-las de misantrópoles. Do grego misanthropos, que refere-se àquele que tem aversão à sociedade, que evita a convivência, que é solitário, insociável, antropófobo. O verbete, segundo os principais dicionários, pode, por associação, ser estendido ao conceito de melancólico. Pois é isso o que se tem quando dois grupos sociais tão díspares como os aqui abordados não mais se encontram no espaço urbano e tampouco compartilham um conjunto mínimo de valores e uma medida comum através da qual possam estabelecer o diálogo, marcar as distinções e interagir socialmente.

A cidade vive e enquanto viver será objeto de disputa. O que é característico dela agora é o aprofundamento radical das distâncias não apenas sociais e materiais, mas sobretudo valorativas. Se, por um lado, alguns estratos adotam a tática coti- diana de evitar a convivência da aversão ao ambiente que lhes é externo, estranho, diverso, por outro lado, outros indivíduos não conseguem apreender e compreender a magnitude das transformações a que estão sendo submetidos. O exemplo do Vetor Sudoeste é, mais uma vez, emblemático neste sentido. Nele estão colocados frente à frente dois contingentes que experimentam trajetórias sociais opostas, ocasionadas pela mesma dinâmica econômica: enquanto à margem esquerda os favelados perdem o seu lugar no mundo, na margem direita os executivos fazem do mundo o seu lugar. Se é faculdade dos homens, como nos diz Simmel, construir caminhos, erguendo pontes para vincular aquilo que, em princípio, na natureza, não tinha vinculação alguma, e erguendo portas para separar aquilo que originalmente era vinculado, é possível dizer que as pontes que interligam as duas margens do Pinheiros estão hoje, e por enquanto, fechadas.

A conformação socioespacial da região sudoeste da cidade de São Paulo evidencia um processo de constante reposição de desigualdades, produzidas e reproduzidas a cada novo ciclo de expansão econômica que o país atravessa. Mais do que herdeiro de um pesado fardo socioeconômico, o Brasil é penalizado por seu próprio presente e possivelmente pelo seu futuro, que inauguram novos padrões de desigualdade social, agravados, de fato, no caso brasileiro, pela herança anterior. A atualidade da pobreza se acentua na medida em que os pobres são cada vez mais penalizados pelo conjunto de transformações estruturais que atinge a sociedade brasileira e têm a sua inserção plena na economia de mercado e nos direitos da cidadania mais uma vez adiada e talvez definitivamente comprometida.

Cabe ressaltar, contudo, que o caso aqui abordado aponta não exatamente para uma cidade e, consequentemente, uma sociedade, extremamente polarizada entre ricos e pobres, entre globalizados e excluídos, ou entre insiders e desconectados, mas mais propriamente para a construção, a partir da crescente desigualdade socioeconômica entre os diversos grupos urbanos, de uma espacialidade caleidoscópica, profundamente dividida em territorialidades com lógicas eco- 
Tabela 2 PrincipaisCorporaçõescujos EscritóriosCentraisno Brasil
Localizam-seno Vetor Sudoeste da Cidade de São Paulo

\begin{tabular}{|c|c|c|c|c|c|}
\hline SETOR & EMPRESA & $\begin{array}{l}\text { PAÍS DE } \\
\text { ORIGEM }\end{array}$ & SETOR & EMPRESA & $\begin{array}{l}\text { PAÍS DE } \\
\text { ORIGEM }\end{array}$ \\
\hline Finanças & $\begin{array}{l}\text { Santander } \\
\text { Deutsche Bank } \\
\text { Sogeral } \\
\text { Lloyds Bank } \\
\text { ABN Amro Bank } \\
\text { Banco Exterior de España } \\
\text { Chase Manhattan Bank } \\
\text { BCN } \\
\text { BEAL West LB } \\
\text { American Express } \\
\text { Visa } \\
\text { BankBoston (futura sede) }\end{array}$ & $\begin{array}{l}\text { Espanha } \\
\text { Alemanha } \\
\text { França } \\
\text { Inglaterra } \\
\text { Holanda } \\
\text { Espanha } \\
\text { EUA } \\
\text { Brasil } \\
\text { Alemanha } \\
\text { EUA } \\
\text { EUA } \\
\text { EUA } \\
\end{array}$ & $\begin{array}{l}\text { Consultoria } \\
\text { empresarial }\end{array}$ & $\begin{array}{l}\text { Andersen } \\
\text { Consulting } \\
\text { Arthur Andersen } \\
\text { Booz Allen } \\
\text { Coopers \& Lybrand } \\
\text { McKinsey } \\
\text { Watson Wyatt }\end{array}$ & $\begin{array}{l}\text { EUA } \\
\text { EUA } \\
\text { EUA } \\
\text { EUA } \\
\text { EUA } \\
\text { EUA }\end{array}$ \\
\hline Tecnologia & $\begin{array}{l}\text { America On Line } \\
\text { Bay Networks } \\
\text { Computer Associates } \\
\text { Compaq } \\
\text { Epson } \\
\text { Ericsson } \\
\text { Hewlett Packard } \\
\text { Intel } \\
\text { Microsoft } \\
\text { Oracle } \\
\text { Sun Microsystems } \\
\text { Texas Instruments } \\
\text { 3COM }\end{array}$ & $\begin{array}{l}\text { EUA } \\
\text { EUA } \\
\text { EUA } \\
\text { EUA } \\
\text { EUA } \\
\text { Suécia } \\
\text { EUA } \\
\text { EUA } \\
\text { EUA } \\
\text { EUA } \\
\text { EUA } \\
\text { EUA } \\
\text { EUA }\end{array}$ & Indústria & $\begin{array}{l}\text { Agfa } \\
\text { Alcan } \\
\text { Alcoa } \\
\text { Bayer } \\
\text { Benetton } \\
\text { BMW } \\
\text { Caterpillar } \\
\text { Ciba-Geigy } \\
\text { Chrysler } \\
\text { Dow Chemical } \\
\text { Gessy Lever } \\
\text { Hoechst } \\
\text { Multibrás } \\
\text { Nestlé } \\
\text { Mobil Oil } \\
\text { Parmalat } \\
\text { PepsiCo. } \\
\text { Pfizer } \\
\text { Philips } \\
\text { Procter \& Gamble } \\
\text { Rhodia } \\
\text { Santista }\end{array}$ & $\begin{array}{l}\text { Bélgica } \\
\text { Canadá } \\
\text { EUA } \\
\text { Alemanha } \\
\text { Itália } \\
\text { Alemanha } \\
\text { EUA } \\
\text { Suíça } \\
\text { EUA } \\
\text { EUA } \\
\text { Hol. / Inglat. } \\
\text { Alemanha } \\
\text { EUA } \\
\text { Suíça } \\
\text { EUA } \\
\text { Itália } \\
\text { EUA } \\
\text { EUA } \\
\text { EUA } \\
\text { EUA } \\
\text { França } \\
\text { Argentina }\end{array}$ \\
\hline Ponto.com & $\begin{array}{l}\text { Yahoo! } \\
\text { Submarino.com } \\
\text { Arremate.com } \\
\text { Viajo.com } \\
\text { Lokau.com } \\
\text { Zeid.com } \\
\text { Latinstocks.com } \\
\text { Ideia.com } \\
\text { Automóvel Online } \\
\text { Organic.com } \\
\text { Submarino.com } \\
\text { Terra.com } \\
\text { StarMedia } \\
\end{array}$ & $\begin{array}{l}\text { EUA } \\
\text { Brasil } \\
\text { Brasil } \\
\text { México } \\
\text { Brasil } \\
\text { Brasil } \\
\text { Brasil } \\
\text { Brasil } \\
\text { Brasil } \\
\text { Brasil } \\
\text { Brasil } \\
\text { Brasil } \\
\text { EUA } \\
\end{array}$ & Telecomunicações & $\begin{array}{l}\text { AT\&T } \\
\text { BCP Celular } \\
\text { GTE } \\
\text { Northern Telecom } \\
\text { HiperNet }\end{array}$ & $\begin{array}{l}\text { EUA } \\
\text { Brasil } \\
\text { EUA } \\
\text { EUA } \\
\text { Brasil }\end{array}$ \\
\hline Mídia & $\begin{array}{l}\text { Rede Globo (sede SP) } \\
\text { Gazeta Mercantil } \\
\text { Reuters } \\
\text { Net }\end{array}$ & $\begin{array}{l}\text { Brasil } \\
\text { Brasil } \\
\text { EUA } \\
\text { EUA }\end{array}$ & $\begin{array}{l}\text { Comércio e } \\
\text { Serviços }\end{array}$ & $\begin{array}{l}\text { Carrefour } \\
\text { Federal Express } \\
\text { Meliá Sol } \\
\text { World Trade Center }\end{array}$ & $\begin{array}{l}\text { França } \\
\text { EUA } \\
\text { Espanha } \\
\text { EUA }\end{array}$ \\
\hline $\begin{array}{l}\text { Entretenimen } \\
\text { to }\end{array}$ & \begin{tabular}{|l} 
Time Warner \\
Cinemark \\
Columbia Tristar \\
Silicon Graphics
\end{tabular} & $\begin{array}{l}\text { EUA } \\
\text { EUA } \\
\text { EUA } \\
\text { EUA }\end{array}$ & Mercado imobiliário & $\begin{array}{l}\text { Bratke Collet } \\
\text { Birmann / Turner } \\
\text { Mackenzie Hill } \\
\text { Richard Ellis } \\
\text { Tishman Speyer }\end{array}$ & $\begin{array}{l}\text { Brasil } \\
\text { Brasil / EUA } \\
\text { EUA } \\
\text { EUA } \\
\text { EUA }\end{array}$ \\
\hline
\end{tabular}

Fonte: Pesquisa de campo realizada pelo autor. 


\section{IMPACTOS DA MUNDIALIZAÇÃO SOBRE UMA METRÓPOLE PERIFÉRICA $\mathbf{6 7}$}

nômicas e sociais muito particulares e muito distintas no tocante a suas relações com os fluxos de mundialização do capital. São territorialidades contíguas umas às outras, as quais podem vir a caracterizar, nos próximos anos, não apenas a porção sudoeste, mas todo o espaço metropolitano da maior cidade do Hemisfério Sul. ${ }^{19}$ Embora a desigualdade socioespacial possa ser encontrada em diversas metrópoles brasileiras, é em São Paulo que ela se apresenta mais forte, dadas as atribuições que cabem à capital paulista no atual momento de expansão do sistema capitalista em escala planetária. Provavelmente os autores mais céticos em relação ao uso generalizado do conceito de cidade global ou mundial tenham razão, pois ao menos no caso de São Paulo, a cidade não se mundializa uniformemente. O que está se formando na região sudoeste da capital paulista é um enclave global avizinhado de favelas quase completamente reduzidas à dimensão local. Curiosamente, a avenida que separa as duas margens do Pinheiros chama-se Nações Unidas, mas é popularmente conhecida como Marginal. O primeiro nome sugere o cotidiano dos executivos das transnacionais presentes na região. O segundo remete à situação dos habitantes das favelas próximas. Ao lado da avenida está sendo construída uma nova linha de metrô, que atualmente opera de modo parcial. Dentro de algum tempo ela deve atravessar o rio e interligar-se a outra linha, que está sendo construída na outra margem. Talvez a partir de então essas pessoas tão próximas e tão distantes possam se entreolhar dentro de um mesmo vagão. Mas enquanto não surgem no horizonte as primeiras luzes do comboio, permanecemos todos aqui, na Estação Incerteza.

\section{NOTAS}

1 No decorrer do texto utilizo tanto os termos "mundial" quanto "global", mas procuro utilizar o termo "mundialização", em vez de "globalização", por entender que este, embora muito mais difundido na literatura, sofreu nos últimos anos um processo de banalização que parece ter lhe turvado a nitidez conceitual, tendo inclusive sido apropriado por interesses mais voltados a adulações ideológicas do que propriamente à análise criteriosa da realidade social.
2 Como afirma Nicolas, "os espaços que se encontram integrados em forma reticular (de rede) não dependem tanto de seus espaços vizinhos imediatos (não integrados às redes) quanto de lógicas extraterritoriais e não raro extranacionais, que representam justamente o avanço da mundialização sobre a internacionalização" (Cf. Nicolas, 1994).

3 Trata-se do texto "World city formation. An agenda for research and action", publicado no International Journal of Urban and Regional Research, em 1982 e, mais tarde retomado, em 1986, por Friedman, em artigo publicado na revista Development and Change com o título de "The world city hipothesis". Segundo Anthony King, porém, a idéia da cidade mundial como metrópole que concentra parte significativa dos negócios mundiais mais importantes surge com Patrick Geddes em 1915. Fernand Braudel, por seu turno, utilizou o termo "cidade mundial" para denotar o centro de economias-mundo específicas, como centros urbanos de concentração de funções de comando. Friedman e Wolff usam o termo como "a articulação espacial do emergente sistema-mundo de produção e mercados através de uma rede mundial de cidades". Segundo eles, as cidades mundiais são as principais regiões urbanas da rede na qual a maior parte das atividades econômicas mundiais devem estar concentradas; são regiões que jogam um papel vital no grande empreendimento capitalista que organiza o mundo para a extração eficiente de lucro. Saskia Sassen, outra referência nos estudos sobre a urbanização contemporânea, fala em "capacidade de controle global", referindo-se às cidades mundiais, as quais seriam "locais de produção de serviços altamente especializados e funções elevadas de controle e gerenciamento". Ver King, 1990; Friedman, 1986; Friedman e Wolff, 1982.

4 Friedman, 1995; Sassen, 1995, 1998.

5 Octavio Ianni (1996) chega a chamar as "cidades globais" de "cósmopoles", não apenas por concentrarem as funções decisórias da economia mundial, mas porque, "de tanto crescer pelo mundo afora, a cidade global adquire características de muitos lugares. As marcas de outros povos, diferentes culturas, distintos modos de ser podem concentrar-se e conviver no mesmo lugar, como síntese de todo o mundo".

6 Fainstein, Gordon e Harloe, 1992; Benko, 1996.

7 Penso aqui na própria argumentação de Sassen desenvolvida em obras recentes, na qual ela afirma que o mercado de trabalho das metrópoles tende a uma polarização funcional e salarial, cuja forma seria uma ampulheta. Edmond Preteceille (1994), que há anos pesquisa as transformações da economia da 
Paris, ressalta, entretanto, que as atividades mais globalizadas representam uma parte relativamente pequena do emprego urbano, o que implica a relativização da tendência de dualidade social a partir da reestruturação do mercado de trabalho.

8 O termo underclass foi cunhado por Gunnar Myrdal, em 1962, para fazer referência aos indivíduos situados à margem da economia. O termo passou a ser freqüentemente usado por sociólogos norte-americanos, a partir de então, para se referir aos trabalhadores mal pagos, não brancos e, em especial, imigrantes, situados no último degrau da estrutura ocupacional dos EUA. Ganhou, nos EUA, conotação racial e passou a referir-se sobretudo aos habitantes dos guetos negros urbanos. Mais recentemente, a partir dos anos de 1980, o termo underclass passou a ter uso mais generalizado, quando os níveis de desemprego atingiram padrões até então inexistentes, e começou a ser aplicado inclusive à realidade européia, onde não teve qualquer conotação racial. O termo é usado hoje em dia para se fazer referência a todos aqueles indivíduos cuja inserção no mercado de trabalho é frágil ou inexistente em um grande número de sociedades capitalistas avançadas, e alguns autores, diante do agravamento das disparidades socioeconômicas em curso nas mais variadas sociedades, avançadas ou não, já deixaram de utilizar o termo e adotaram o neologismo undercaste para fazer referência aos contingentes acima citados. No entanto, o termo underclass é ainda utilizado pelos conservadores morais e pelos economistas neoliberais para se referir aos indivíduos que não se adaptam à sociedade por suposta fraqueza individual e moral, motivados pela natureza assistencial do Welfare State. Segundo esta ótica, os indivíduos da underclass criam uma subcultura desviante, evidente nos bairros decadentes das grandes metrópoles. William Julius Wilson, prestigiado sociólogo norte-americano de orientação progressista, por sua vez, sustenta que o declínio do emprego industrial e o crescimento de empregos precários no setor terciário empurraram para fora do mercado de trabalho os contingentes menos qualificados, como negros e hispânicos. Estes contingentes teriam sido deslocados para a economia informal e para o crime, ou quando muito para uma posição altamente insegura e marginal dentro do mercado de trabalho. Ver, a esse respeito, Gans, 1996; Wacquant, 1996 e Wilson, 1996.

9 Cabe notar que, embora a região já contasse com uma série de equipamentos públicos, foram priorizados, no decorrer dos anos de 1990, novos investimentos infra-estruturais, em especial no setor de transportes, com a abertura de novas avenidas, túneis e a construção de oito novas estações de trem ao longo da Marginal Pinheiros, sob um traçado que em breve deverá ser transformado na linha 5 do Metropolitano de São Paulo.

10 Diversos termos são utilizados, na literatura, para fazer referência à região da capital paulista aqui retratada, como "quadrante", "porção", "setor" etc. Utilizo o termo "vetor" para realçar tanto o sentido de direção para onde se cria a mais nova centralidade paulistana quanto as possibilidades daquilo que a cidade pode vir a ser no futuro, dada a dinâmica que preside o seu desenvolvimento, tendo em vista as novas peculiaridades da polarização socioespacial que está sendo construída naquela parcela do espaço paulistano.

11 A região que se inicia a partir da margem esquerda do rio Pinheiros, em direção ao sul e sudoeste da Grande São Paulo constitui a porção mais pauperizada da periferia da metrópole, contando com altos índices de desemprego e violência. Nela destacamse bairros como Campo Limpo, Capão Redondo e Jardim Ângela.

12 Cf. "A nova arquitetura paulistana: o pós-modernismo da marginal Pinheiros substitui o modernismo da Paulista”. Gazeta Mercantil, 21/06/1996.

13 Ver, a esse respeito, o trabalho de Mariana Fix (1996), a respeito da remoção recente do conjunto de favelas situado no entorno do que é, atualmente, a Avenida das Águas Espraiadas, levada a cabo por iniciativa da Prefeitura Municipal de São Paulo, gestão 1992-1996.

14 Segundo a Pesquisa Emprego e Desemprego do convênio Seade/Dieese, era a seguinte a distribuição dos ocupados no município de São Paulo, segundo a escolaridade, no ano de 1997: 3,7\% de analfabetos, 39,3\% de indivíduos com o $1^{\circ}$ grau incompleto, $18,1 \%$ dos indivíduos com o $2^{\circ}$ grau incompleto, $22,6 \%$ de indivíduos com o $3^{\circ}$ grau incompleto e $16,3 \%$ com o $3^{\circ}$ grau completo. Não havia na pesquisa dados sobre pós-graduados, mas é possível pressupor que sejam uma proporção bastante diminuta do mercado de trabalho.

15 Segundo o Mapa da Exclusão Social, elaborado pela PUC em 2000 e publicado em 24 de setembro daquele ano pela Folha de São Paulo, eram as seguintes as taxas de homicídios, para cada 100 mil habitantes, entre a população de 15 a 24 anos, em cinco distritos da periferia sul da cidade de São Paulo, no ano de 1999: Jardim Ângela, 206,87; Jardim São Luís, 186,85; Grajaú, 185,55; Capão Redondo, 166,50; Campo Limpo, 142,98. A taxa média de homicídios na cidade de São Paulo no mesmo ano era de 121,33 para cada 100 mil habitantes entre 15 e 24 anos. O Grajaú, o Jardim Ângela e o Jardim São 
Luís, contíguos ao Vetor Sudoeste, ocupavam em 1999 a primeira, a segunda e quinta posições, respectivamente, no número absoluto de homicídios de jovens no município de São Paulo.

16 Penso aqui nas torres da Marginal Pinheiros em oposição à idéia das casas de vidro de que nos fala Benjamin (1985).

17 Trata-se do edifício Birmann 20, sede da Microsoft no Brasil.

18 Ver o artigo "Cidade virtual desmaterializa a cidade real". O Estado de São Paulo, 20/10/1996.

19 A hipótese da transformação das metrópoles em espaços não propriamente dualizados, mas sobretudo fragmentados, vem sendo defendida por Edmond Preteceille (1994) e reforçada por Luiz César Queirós Ribeiro (2000).

\section{BIBLIOGRAFIA}

ANDRADE, Carlos Roberto M. (1997), "Confinamento e deriva: sobre o eclipse do lugar público na cidade moderna", in Célia F. Souza \& Sandra J. Pensavento (orgs.), Imagens Urbanas: os diversos olhares na formação do imaginário urbano, Porto Alegre, Editora da UFRGS.

BENJAMIN, Walter. (1985), "Experiência e Pobreza", in Walter Benjamin, Obras escolbidas, vol. 1: Magia e técnica, arte e politica (trad. de Sérgio Paulo Rouanet), São Paulo, Brasiliense.

BENKO, Georges. (1996), "Organização econômica do território: algumas reflexões sobre a evolução no século XX", in Milton Santos; Maria Adélia Souza e Maria Laura Silveira (orgs.), Território: globalização e fragmentação, São Paulo, Hucitec/Anpur.

BONDUKI, Nabil. (1994), "Crise da habitação e luta pela moradia no pós-guerra”, in Lúcio Kowarick, As lutas sociais e a cidade: São Paulo, passado e presente, Rio de Janeiro, Paz e Terra.

CASTELLS, Manuel. (2000), A sociedade em rede (trad. de Roneide Venâncio Majer). São Paulo, Paz e terra.

DURHAN, Eunice. (1978), A caminho da cidade: a vida rural e a migração para São Paulo. São Paulo, Perspectiva.
FAINSTEIN, S; GORDON, I. \& HARLOE, M. (eds.). (1992), Divided cities: New York and London in the contemporary world. Cambridge, Blackwell Publishers.

FIX, Mariana. (1996), "O Estado e o capital nas margens do Rio Pinheiros - duas intervenções: Faria Lima e Água Espraiada”. Trabalho de Graduação Interdisciplinar, Faculdade de Arquitetura e Urbanismo da Universidade de São Paulo.

FORRESTER, Viviane. (1997), O horror econômico (trad. de Álvaro Lorencini). São Paulo, Editora da Universidade Estadual Paulista.

FRIEDMAN, John. (1995), "Where we stand: a decade of world city research", in Paul Knox e Peter Taylor, World cities in a world-system, Cambridge, Cambridge University Press.

(1986), "The world ity hypothesis". Development and Change, 17 (1): 69-84.

FRIEDMAN, John \& WOLFF, Goertz. (1982), "World city formation: an agenda for research and action". International Journal of Urban and Regional Research, 6 (3): 309-344.

FRÚGOLI JÚNIOR, Heitor. (1998), O centro, a avenida Paulista e a avenida Luiz Carlos Berrini na perspectiva de suas associações: centralidade urbana e exclusão social. Tese de doutorado apresentada ao Departamento de Sociologia da Faculdade de Filosofia, Letras e Ciências Humanas da Universidade de São Paulo.

FUJIMOTO, Nelson. (1994), A produção monopolista do espaço urbano e a desconcentração do terciário de gestão na cidade de São Paulo: o caso da avenida Engenheiro Luiz Carlos Berrini. Dissertação de mestrado apresentada ao Departamento de Geografia da Faculdade de Filosofia, Letras e Ciências Humanas da Universidade de São Paulo.

GANS, Herbert. (1996), "From 'underclass' to 'undercaste': some observations about the future of the post-industrial economy and its major victims", in Enzo Mingione, Urban Poverty and the underclass: a reader, Oxford, Blackwell Publishers.

IANNI, Octavio. (1996), A era do globalismo. Rio de Janeiro, Civilização Brasileira. 
KING, Antonhy. (1990), Global cities: post-imperialism and the internationalization of London. Londres, Routledge \& Kegan Paul.

KOWARICK, Lúcio. (1994), As lutas sociais e a cidade: São Paulo, passado e presente. Rio de Janeiro, Paz e Terra.

LYNCH, Kevin. (1960), A imagem da cidade. Lisboa, Martins Fontes.

MARICATO, Ermínia. (1996), Metrópole na periferia do capitalismo. São Paulo, Hucitec.

NICOLAS, Daniel H. (1994), "Tempo, espaço e apropriação social do território: rumo à fragmentação na mundialização?, in Milton Santos; Maria Adélia Souza e Maria L. Silveira (orgs.), Território, globalização e fragmentação, São Paulo, Hucitec/Anpur.

PECHMAN, Roberto M. (1997), "A cidade dilacerada", in Célia F. Souza e Sandra J. Pensavento (orgs.), Imagens urbanas: os diversos olhares na formação do imaginário urbano, Porto Alegre, Editora da UFRGS.

PRETECEILLE, Edmond. (1994), "Cidades globais e segmentação social”, in Luiz César Queirós Ribeiro e Orlando Santos Jr. (orgs.), Globalização, fragmentação e reforma urbana: o futuro das cidades brasileiras na crise, Rio de Janeiro, Civilização Brasileira.

RANCIÈRE, Jacques. (1996), O desentendimento (trad. de Ângela Leite Lopes). São Paulo, Editora 34.

RIBEIRO, L. C. de Q. (2000), "Cidade desigual ou cidade partida? Tendências da metrópole do Rio de Janeiro", in L. C. de Q. Ribeiro (org.), O futuro das metrópoles: desigualdades e governabilidade, Rio de Janeiro, Revan/Fase.

(org.). (2000), O futuro das metrópoles: desigualdades e governabilidade. Rio de Janeiro, Revan/Fase.

RIBEIRO, Luiz César Queirós \& SANTOS JR., Orlando (orgs.). (1994), Globalização, fragmentação e reforma urbana: o futuro das cidades brasileiras na crise, Rio de Janeiro, Civilização Brasileira.

ROLNIK, Raquel. (1994), "São Paulo, início da industrialização: o espaço e a política", in Lúcio Kowarick (org.), As lutas sociais e a cidade, Rio de Janeiro, Paz e Terra.
SADER, Eder. (1988), Quando novos personagens entraram em cena: experiências e lutas dos trabalhadores da Grande São Paulo, 1970-1980. Rio de Janeiro, Paz e Terra.

SANTOS, Milton. (2000), Por uma outra globalização: do pensamento único à consciência universal. Rio de Janeiro, Record.

(1990), Metrópole corporativa fragmentada: o caso de São Paulo. São Paulo, Secretaria de Estado da Cultura/Nobel.

SANTOS, Milton; SOUZA, Maria Adélia \& SILVEIRA, Maria L. (orgs.). (1994), Território, globalização e fragmentação, São Paulo Hucitec/Anpur.SASSEN, Saskia. (1998), Globalization and Its discontents: essays on the new mobility of people and money. Nova York, The New Press.

(1995), "On concentration and centrality in the global city", in Paul Knox e Peter Taylor, World cities in a world-system, Cambridge, Cambridge University Press.

SIMMEL, Georg. (1986), "Puente y puerta", in Georg Simmel, El indivíduo y la libertad: ensayos de crítica de la cultura, Barcelona, Ediciones Península.

SINGER, Paul. (1975), Economia política da urbanização. São Paulo, Brasiliense/Cebrap.

WACQUANT, Louis. (1996), "Red belt, black belt: racial division, class inequality and the State in the French urban periphery and the American ghetto", in Enzo Mingioni, Urban poverty and the underclass: a reader, Oxford, Blackwell Publishers.

WILSON, William Julius. (1996), When work disappears: the world of the new urban poor. Nova York, Alfred A. Knopf.

\section{Artigos de jornal}

"Cidade virtual desmaterializa a cidade real". O Estado de São Paulo, 20/10/1996.

"A nova arquitetura paulistana: O pós-modernismo da marginal Pinheiros substitui o modernismo da Paulista". Gazeta Mercantil, 21/06/1996. 


\section{IMPACTOS DA MUNDIALIZA- ÇÃO SOBRE UMA METRÓPO- LE PERIFÉRICA}

\section{Wagner Iglecias}

\section{Palavras-chave}

São Paulo; Metrópole; Mundialização do capitalismo; Corporações transnacionais; Favelas; Sociabilidade.

Este artigo analisa alguns dos novos arranjos de sociabilidade que surgiram na cidade de São Paulo em anos recentes. Isto se deu em virtude de uma paulatina modificação da vocação econômica da metrópole - de um tradicional perfil industrial, tornou-se um grande centro de comércio e serviços. O recorte aqui utilizado refere-se à região sudoeste do município, onde vem se concentrando, sobretudo a partir da década de 1990, as sedes brasileiras de inúmeras corporações transnacionais do setor terciário avançado, no mesmo espaço geográfico ocupado há anos por populações de baixa renda. Acreditamos que os novos vizinhos nem estabelecem comunicação, nem compartilham valores comuns. É provável também que eles estejam desligando uma parte significativa de seus laços com o espaço públco e com os demais contingentes populacionais presentes na metrópole.

\section{GLOBALIZATION IMPACTS ON A PERIPHERAL METROPOLIS}

\author{
Wagner Iglecias
}

\section{Keywords}

São Paulo; Metropolis; Capitalism Globalization; Transnational Corporations; Slums; Sociability.

This article analyses some of the new sociability arrangements that have appeared in the city of São Paulo in recent years. Such transformation has happened due to the steady changing of the metropolis's economical vocation - from a fairly traditional industrial profile to a huge commerce and service center. The detailed analysis refers to the city's southwest area, where countless transnational corporations of the advanced tertiary sector have chosen their headquarters to be, especially in the 1990's, in the same geographical area that had been occupied by low-income population. We believe the newcomers neither establish communication nor share common values. It is probable that a significant part of their links to the public space has been disrupted, as well as their connection to other kinds of population found in the metropolis.

\section{IMPACTS DE LA MONDIALISATION SUR UNE MÉTROPOLE PÉRIPHÉRIQUE}

\author{
Wagner Iglecias
}

\section{Mots-clés}

São Paulo; Métropole;

Mondialisation du capitalisme;

Corporations transnationales;

Bidonvilles; Sociabilité.

Cet article analyse certains des nouveaux arrangements de sociabilité qui sont apparus dans la ville de São Paulo au cours de ces dernières années. Cela a eu lieu en vertu d'une modification graduelle de la vocation économique de la métropole - d'un profil industriel traditionnel vers un grand centre de commerce et de services. Le découpage que nous utilisons ici se rapporte à la région sud-ouest de la commune, dans laquelle se concentrent, surtout à partir des années 1990, les sièges brésiliens d'innombrables corporations transnationales du secteur tertiaire avancé, dans le même espace géographique occupé depuis des années par des populations à bas revenus. Nous sommes persuadés que les nouveaux voisins n'établissent ni de communication, ni ne partagent des valeurs communes. Il est probable qu'ils seraient en train d'abandonner une partie significative de leurs liens avec l'espace public et avec les autres contingents de la population présents dans la métropole. 